\title{
THE STUDY OF THE EARLY BYZANTINE ARCHITECTURE OF CHERSONESOS IN THE CRIMEA: PROGRESS OR DEAD END?*
}

\section{LIUDMILA G. KHRUSHKOVA}

$\begin{aligned} & \text { UDC: } 726.591(477.75) \\ & 72.033 .2(477.75)\end{aligned}$

Original scientific paper

Manuscript received: 10. 11. 2016.

Revised manuscript accepted: 28. 11. 2016.

DOI: 10.1484/J.HAM.5.113768
L. G. Khrushkova

Lomonosov Moscow State University Lomonosovsky Prospekt 27-4

Moscow 119992, Russia KhrushkovaL@list.ru

The Early Christian basilicas of Chersonesos in the Crimea have been studied for over a century and a half. There are about 20 monuments known today; almost all of them were discovered in the late $19^{\text {th }}$ and early $20^{\text {th }}$ centuries. Despite this, they remain poorly studied. Anatolij L. Yakobson's book "Early Medieval Chersonesos" (1959) remains the only generalizing work in which the architecture, the mosaic and marble décor of the churches are examined together and in the context of the history of the city. This outcome is due largely to the way in which Chersones has been studied. During the last decades of the $19^{\text {th }}$ century and the first decades of the $20^{\text {th }}$ century, the main role was played by the St Petersburg Archaeological Commission. Unfortunately, it never succeeded in assigning professional archaeologists and architects to the works in Chersonesos. Because of this, we don't have exact information regarding the current location of many of the finds; also absent is a precise documentation (plans, sections, elevations, details) for the greater part of the architectural monuments of Chersonesos. It reveals that in the post-Soviet era, the "item-centric" approach has prevailed: the fragments of ceramics and the coins were analyzed rather than the architecture. The meaning of the large collection of marble works from Proconnesos' workshops is completely denied for the dating of the monuments.

Keywords: Byzantium, Crimea, Chersonesos, history of researches, Byzantine architecture, excavations, stratigraphic method, marbles, mosaics, episcopal basilica.

The fate of archaeology in our country is a sad one... Nikodim P. Kondakov

The Byzantine architecture of the Chersonesos in Crimea ${ }^{1}$ has now been studied for almost two centuries. The bishop's

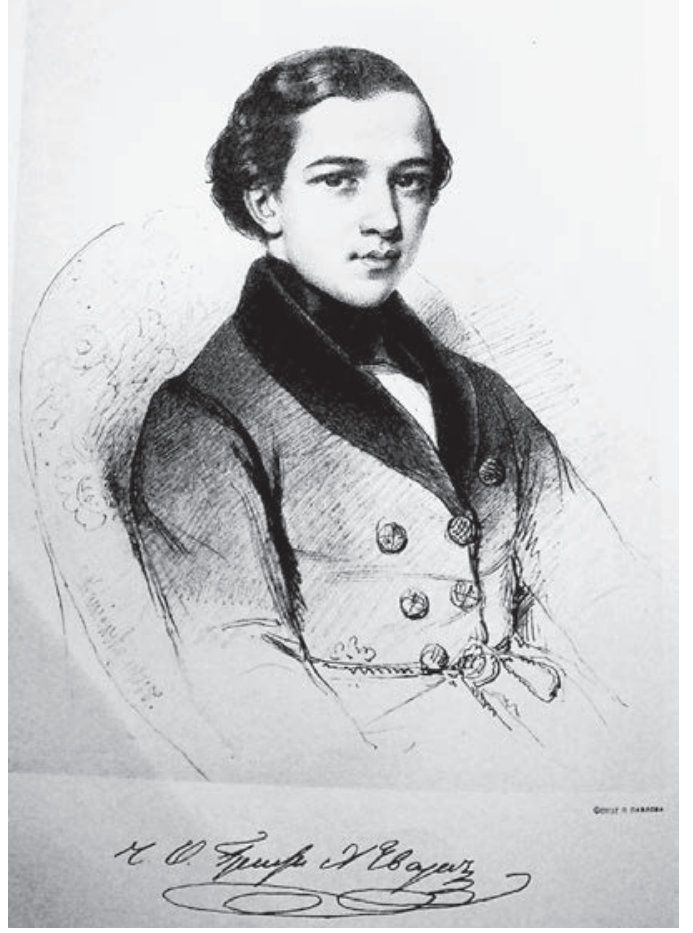

Fig. 1. Alexej S. Uvarov (after: A. S. Uvarov, 1910, Front page) basilica discovered by Count Alexei Sergeevič Uvarov (18281884) in $1853^{2}$ (fig. 1, 2, 3) which was named by him is well known to European scholars 3 . It is Chersonesos that was originally singled out among the ancient towns of the region called "the South of Russia" as the field for Byzantine studies. Nikodim Pavlovič Kondakov (1844-1925), who was the most prominent figure in the field of Byzantine studies in Russia ${ }^{4}$, wrote: «The significance of Chersonesos lies not in the

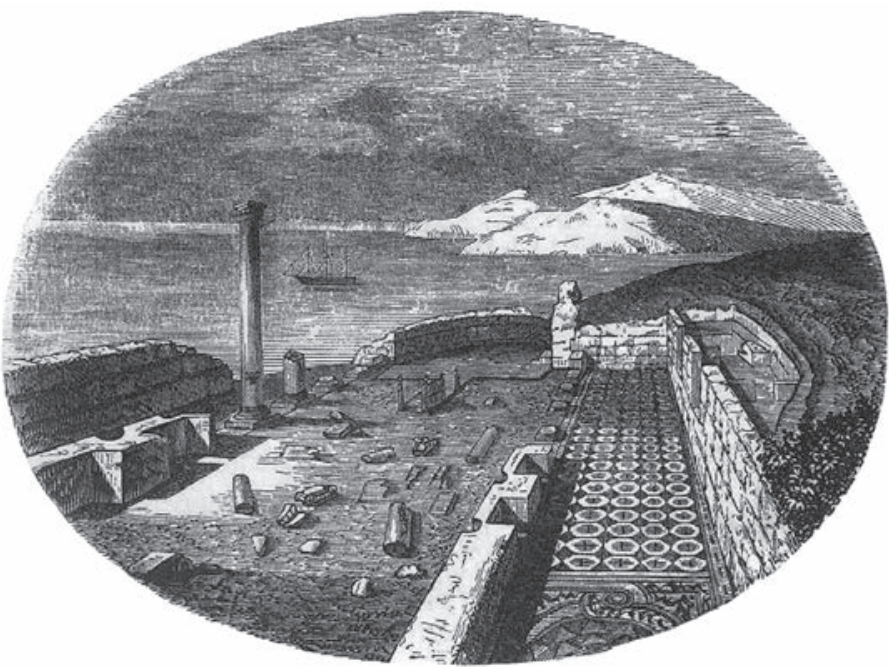

Fig. 2. Uvarov's basilica, lithography (after: A. S. Uvarov, 1854)

* Translation by Zoya Metlitskaya.

${ }^{1}$ In Byzantine sources from the $6^{\text {th }}$ century onwards, the town is called Cherson.

${ }^{2}$ A. UVAROV, Neskol'ko slov ob arkheologičeskikh razyskaniakh bliz Simferopoliya i Sevastopoliya, in Propilei. Sbornik statej po klassičeskoj drevnosti 4 , Moscow, 1854, p. 525-538; ID., Arkheologičeskie issledovaniya bliz Simferopoliya i Sevastopoliya, in Izvlečenie iz vsepoddannejšego otčeta o arkheologičeskikh razyskaniyakh $v 1853$ godu, Sankt-Petersburg, 1855.

${ }^{3}$ H. LECLERCQ, Caucase, in DACL II, Paris, 1910, col. 2641-2644; ID., Crimée, in DACL III, 2, Paris, 1914, col. 3038-3039.

4 I. L. KYZLASOVA, Nikodim Pavlovič Kondakov, in Pravoslavnaya Entsiklopediya 34, Moscow, 2014, p. 599-601; L. G. KHRUSHKOVA, Nikodim P. Kondakov, in S. Heid, M. Dennert (eds.), Personenlexikon zur christlichen Archäologie 2, Regensburg, 2012, S. 751-754. 


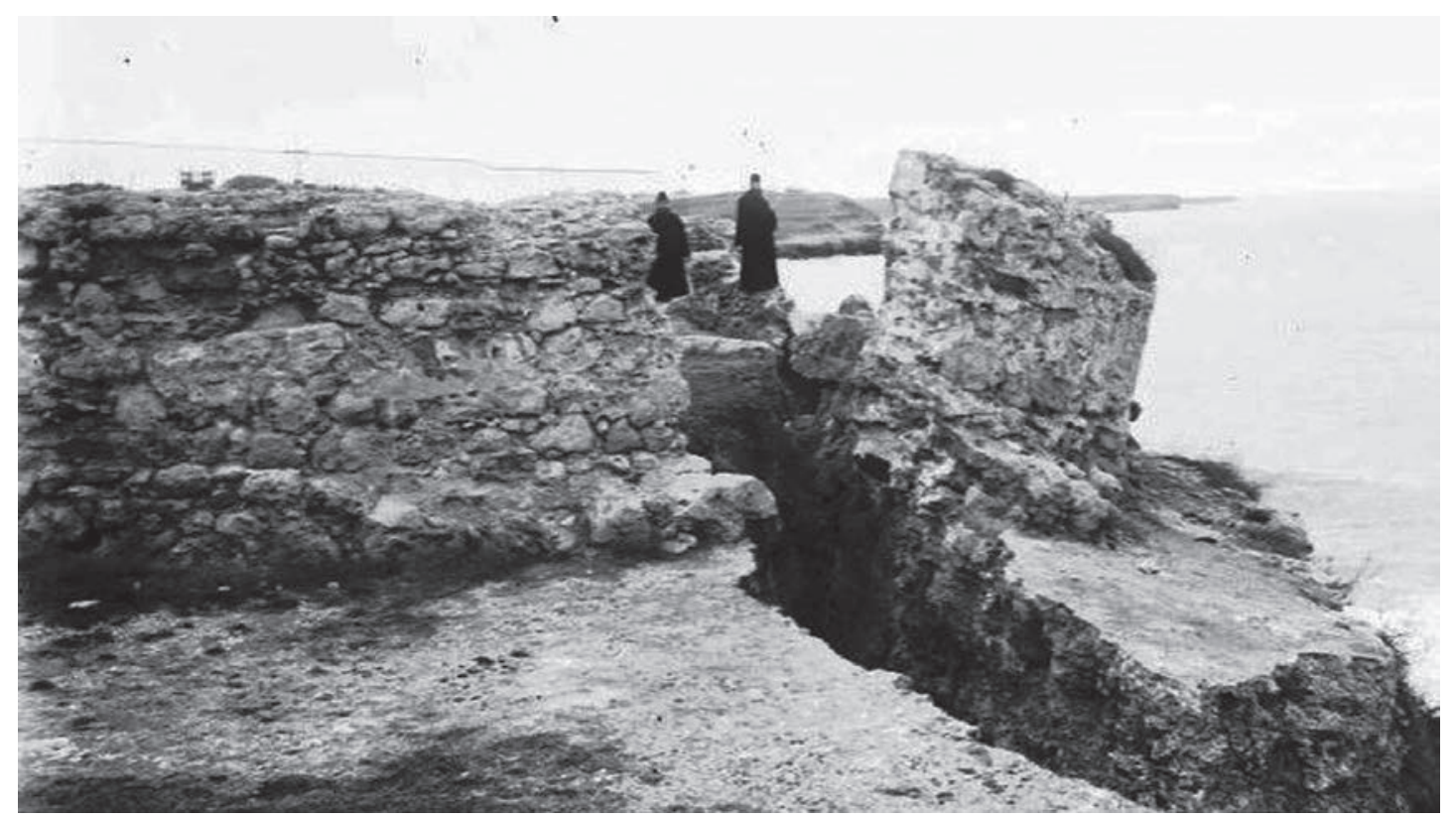

Fig. 3. Uvarov's basilica, view of the apse (The State Historical and Archaeological Museum-Preserve "Tauric Chersonese", Archives)

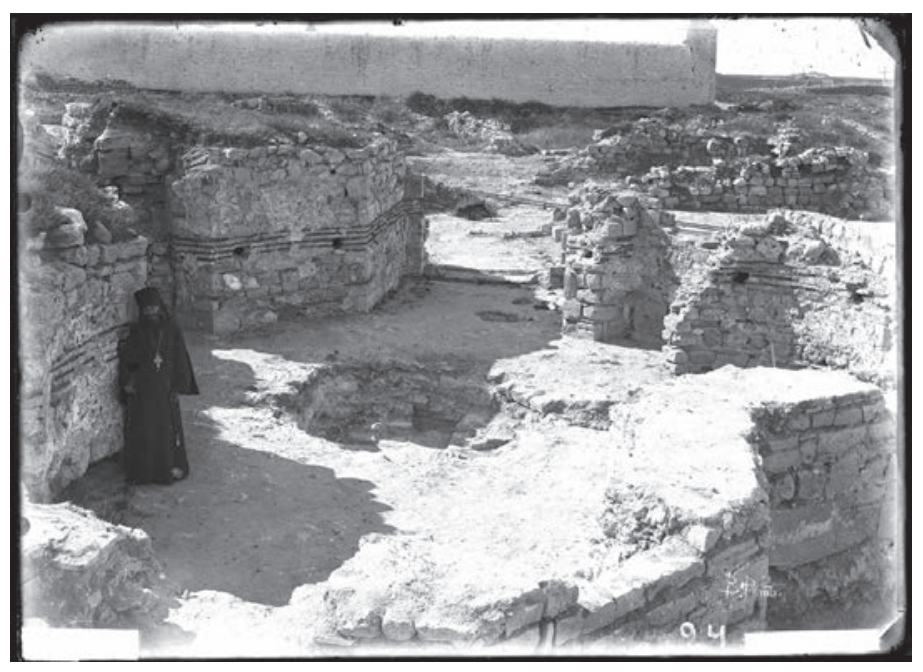

Fig. 4A. Complex of Uvarov's basilica. Baptistery, view to the West (The State Historical and Archaeological Museum-Preserve "Tauric Chersonese", Archives)

monuments of Antiquity; it is just about the only place for discovering the findings of Byzantine past», above all, ecclesiastical buildings and their marble pillars with capitals 5 .

The long history of the studies of Uvarov's basilica ${ }^{6}$ reflects the whole history of the research of Byzantine architecture in the Crimea. In $1870-1880$, the main role in the investigations in the town belonged to the Odessa Society of History and Antiquities ("Odesskoe Obščestvo Istorii i Drevnostei”, OOID); the local St. Vladimir monastery also took

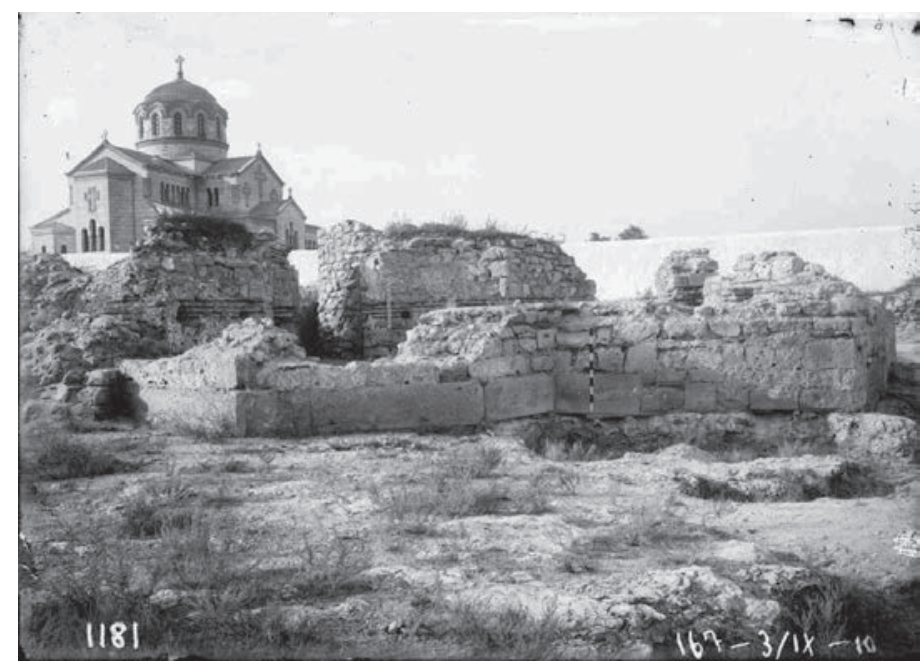

Fig. 4B: Complex of Uvarov's basilica. Baptistery, view to the South-West, from the basilica (The State Historical and Archaeological Museum-Preserve "Tauric Chersonese", Archives)

part in the activity, but this period was not very successful. "It's very strange", - wrote a contemporary observer - "that in this country historical monuments and places are neglected by public opinion ... sites that in the foreign lands would be virtually clothed in ornamented scaffolding, are standing here as a wilderness ... or as backyards!" 8 But there was also some good luck, such as the discovery of the baptistery of Uvarov's basilica (fig. 4).

\footnotetext{
${ }_{5}^{5}$ N. P. KONDAKOV, Book review: A. L. BERTHIER-DELAGARDE, Drevnosti Yužnoj Rossii. Raskopki Khersonesa, Sankt-Petersburg, 1893, in Žurnal Ministerstva Narodnogo Prosveščeniya 2, 1, Sankt-Petersburg, 1893, p. 390.

${ }^{6}$ E. IY. KLENINA, Uvarovskaya bazilika (No 23), in A. B. Biernacki et al. (eds.), Rannevizantijskie sakral'nye postrojki Khersonesa Tavričeskogo, Poznañ, 2004, p. 71-75; L. G. KHRUSHKOVA, Khristianskie pamyatniki Kryma (sostoyanie izučeniya), in VV 63 (88), Moscow, 2004, p. 167-194; A. I. POMANČUK, Issledovaniya Khersonesa-Khersona. Raskopki. Gipotezy. Problemy 2. Vizantijskij period, Tyumen', 2008, p. 275-284; S. A. BELYAEV, Neobkhodimost sistemno-informatsionnogo podkhoda pri issledovanii častnykh i lokal'nykh sobytij (na primere izučeniya Uvarovskoj baziliki v Khersonese), in S. A. Beliaev (ed.), Očerki po istorii khristianskogo Khersonesa, Sankt-Petersburg, 2009, p. 90-108.

${ }^{7}$ A. V. ŠAMANAEV, Deyatel'nost Odesskogo Obščestva istorii i drevnostej po izučeniyu Khersonesa, in Antičnaya Drevnost i Srednie Veka 34, Ekaterinburg, 2003, p. 415-425.

${ }^{8}$ F. V. Livanov, the author of Crimea travel guide,1875: A. V. ŠAMANAEV, Proekt issledovanij okhrany Khersonesskogo gorodišča Odesskogo Obščestva istorii i drevnostej 1876 g., in Khersonesskij Sbornik 17, Sevastopol'; Sankt-Petersburg, 2012, p. 217.
} 


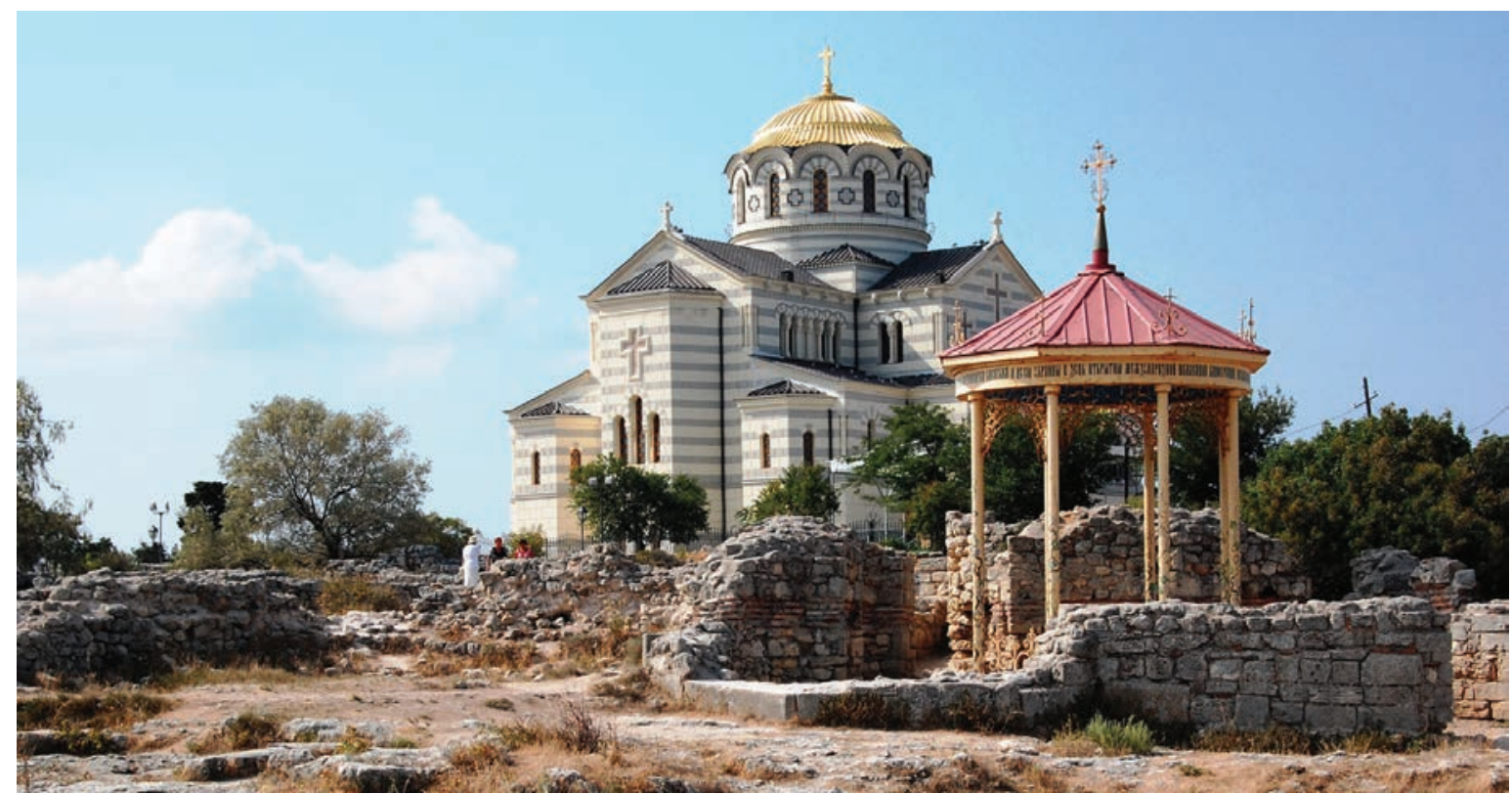

Fig. 5. Complex of Uvarov's basilica. Baptistery, view to the South (photo L. Khrushkova)

\section{“A BRILLIANT EPOCH"?}

The president of the Moscow Archaeological Society Countess Praskoviya Sergeevna Uvarova (1840-1924) ${ }^{9}$ (fig. 6), being anxious about the unfavorable situation in Chersonesos, wrote bravely and resolutely, as was her custom, to Emperor Alexander III on June 5, 1887. She pointed out that the desolation in Chersonesos "is increasing year by year and ... that really would stand as a rebuke to any true Russian". The Emperor agreed, being himself astonished at "these outrages". Uvarova proposed "to establish a special archaeological station on the site" and if this were done then "the ancient Chersonesos would be a Russian Pompeii" ${ }^{\circ}$. Using the term "an archaeological station," Uvarova spoke the language of her time. She really meant the organization in Chersonesos to be a permanent research center, such as the Deutsche Archäologische Institut in Rome or the École Française d'Athènes.

Uvarova's idea was undoubtedly the only correct one, but in reality the deve-

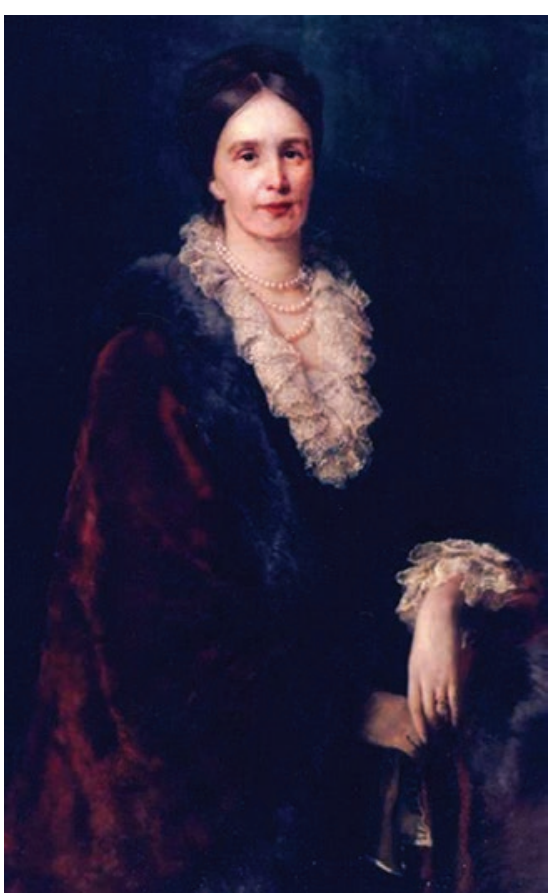

Fig. 6. Praskovya S. Uvarova

(K. E. Makovskij, 1882, private collection, after: P. S. Uvarova, 2005)

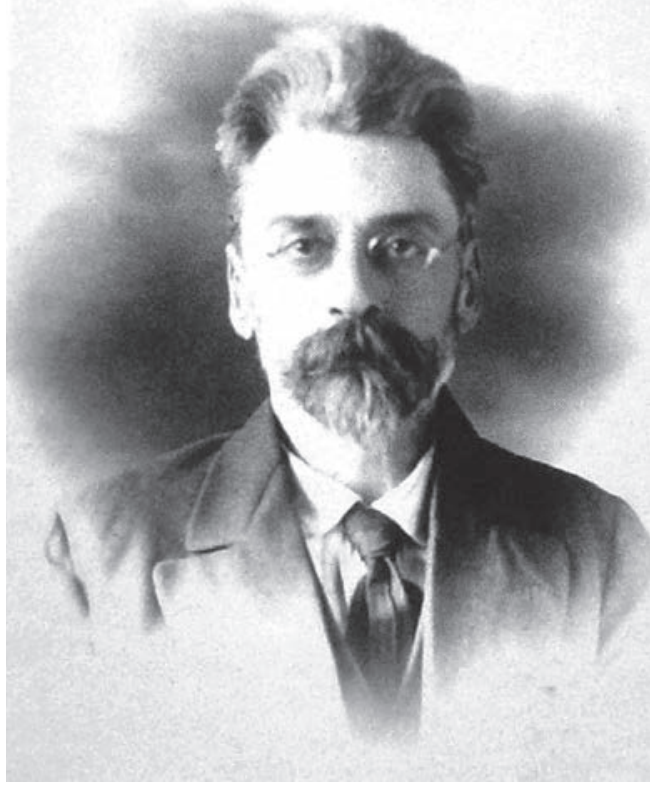

Fig. 7. Dmitrij V. Ainalov

(after: I. L. Kyzlasova, ed., 2004) lopments were very different. The Emperor took his decision very rapidly, and after 1887 the excavations in Chersonesos were conducted under the guidance of Russia's main archaeological foundation, the Sankt-Petersburg Archaeological Commission, headed by Count Alexej Alexandrovič Bobrinskij (1852-1927) ${ }^{11}$. In 1888 the work began «under the supervision of professor Nikodim P. Kondakov» ${ }^{12}$. His research focused mainly on painting, but he studied also ecclesiastical architecture in Georgia, Constantinople and later - in Palestine. He supervised the excavations for three

years: 1888,1889 and 1890 , but his role was rather formal. During these years Kondakov was engaged in many other scholarly projects: he published the first volume of «Russian antiquities in the art monuments» (1889), the inventories of monastic sacristies in West Georgia (1890), the Catalogue of the items from Medieval and Renaissance department of the Hermitage (1891). He was not very keen on Crimean field archaeology. He wrote in his letter from Kerč on June 18, 1883: «I am here, on the site of excavations, which were boring and fruitless this year, but this work provides me

\footnotetext{
${ }_{9}^{9}$ L. G. KHRUSHKOVA, Geschichte der Christlichen Archäologie in Russland vom 18. bis ins 20. Jahrhundert (2. Folge), in RQ 107, 1-2, 2012, S. 74-81.

${ }^{10}$ A. I. ROMANČUK, Vozvraščenie k staroj teme ili načal'nyj period issledovaniya Khersonesa, in Antičnaya Drevnost i Srednie Veka 35, Ekaterinburg, 2004, p. 247-248.

${ }^{11}$ E. N. Nosov, A. E. Musin (eds.), Imperatorskaya arkheologičeskaya komissiya (1859-1917). K 150-letiu so dnya osnovaniya, Sankt-Petersburg, 2009.

${ }^{12}$ K. E. GRINEVIČ, Sto let khersoneskikh raskopok (1827-1927), Sevastopol', 1927, p. 22-24.
} 
with the money for trips and meetings with people of my stamp, so I must bear all this $»^{13}$. The scholar had in mind his frequent travels abroad, particularly to Rome.

In 1891, Kondakov left the Archaeological Commission because of a conflict with Bobrinskij ${ }^{14}$. For the same reason, those of Kondakov's students who had initially been interested in the excavations in Chersonesos did not participate in them. In 1890, Chersonesos was visited by Dmitrij Vlasievič Ainalov (1862-1939) scholar, a humble Privat-Dozent (Assistant Professor) at the Kazan University (fig. 7). He was going to write his first thesis and was looking for new materials from Chersonesos - architectural monuments, marble items, mosaic pavements. During this time, he made a description of the marbles, but did not complete the job. Ainalov did not agree with the methods of excavation and wrote a long letter to the Archaeological Commission, in which he proposed his own program of investigations ${ }^{16}$. That letter had no effect, and the program has not been realized to this day. The following year Ainalov left for a long trip to Europe; in Rome he wrote a dissertation on wall mosaics. Another student of Kondakov, Egor Kuz'mič Redin $(1863-1908)^{17}$ in 1891 also went to Europe to work on his dissertation on the mosaics of Ravenna. Kondakov himself was in Syria and Palestine in 1891 - he led the expedition of the Imperial Orthodox Palestine Society ${ }^{18}$.

Thus the studies of Chersonesos and the Russian Byzantine studies (which flourished in those years) parted ways quickly - and for long. Saint Petersburg was then a scholarly center with a high international reputation and, in the opinion of recent scholars, excelled Vienna, which dominated European studies in the field ${ }^{19}$. It is not the case that the Archaeological Commission took no interest in Byzantine. In 1893 Bobrinskij opposed the organization of the Russian Archaeological Institute in Constantinople ${ }^{20}$. He himself wrote a brief survey of the history of Chersonesos ${ }^{21}$, which apparently didn't have a great impact on the historiography.

After Kondakov's departure, professional researchers did not return to Chersonesos. It was Karl Kazimirovič Kostsyuško-Valyužinič (1847-1907)22 (fig. 8) who supervised the excavations from 1888 and until his death. He played a crucial role in the study of the town, the peculiarities of his work leaving an imprint on the further development of Chersonesos studies in more ways than one. Being what we would now call "an amateur historian", Karl Kazimirovič was very keen on history and archeology, and he was ready to serve the "science" with selfless enthusiasm. He wrote:

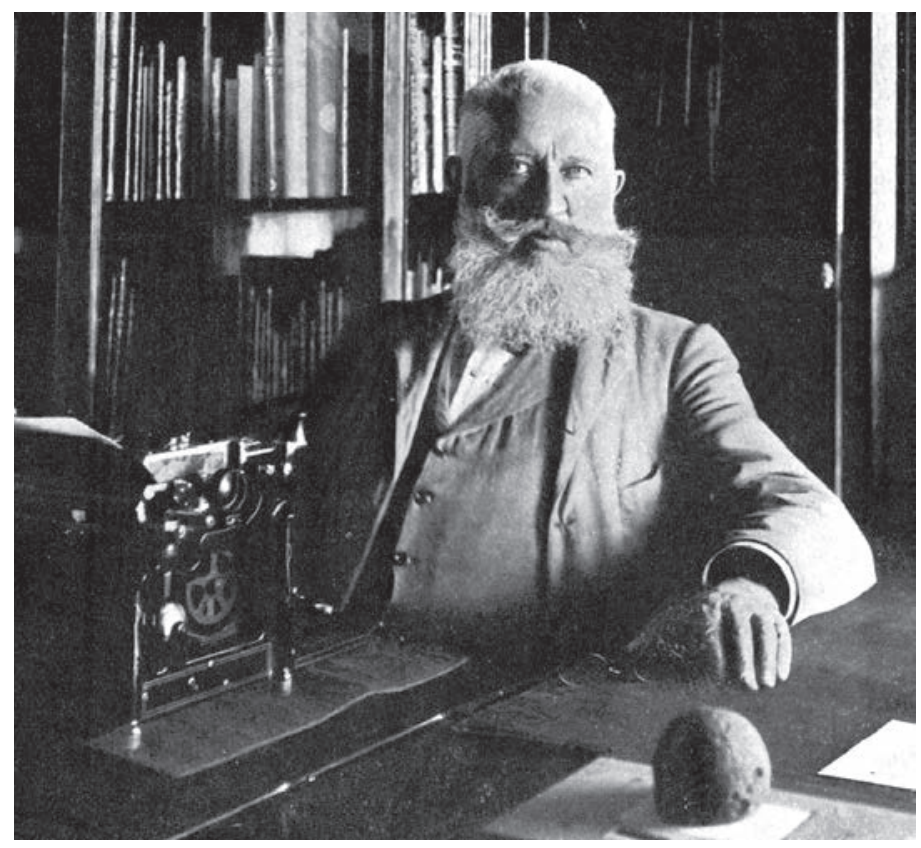

Fig. 8. Karl K. Kostsyuško-Valyužinič (The State Historical and Archaeological Museum-Preserve "Tauric Chersonese", Archives)

"For me to part with Chersonesos is like taking leave of this life." The scope of his work was enormous, "and even now one can be astonished by them". A small group consisting of Kostsyuško-Valyužinič himself, a draftsman and a photographer (not one of the three professionally trained) excavated, described and documented "thousands of monuments. And what monuments! More than 1,0oo meters of defensive walls, the foundations of which lie at a depth of 5 meters, 12 towers, more than 10 large churches and chapels, residential districts, the 2000 graves of the necropolis!"23 Kostsyuško-Valyužinič excavated 18 churches and chapels; these comprised the greater part of the monuments known to us today.

Unfortunately, the quality of excavations didn't match the vigour with which they were performed. The principle of stratigraphy was unknown in Chersonesos. There is still no answer to these simple questions: what is the provenance of many thousands of the finds? From which churches were taken the hundreds of capitals, slabs and columns? (fig. 9, 10). Only a very small part of the architectural details and mosaic floors was sketched, many items were not photographed, many monuments were destroyed and perished. But why was it necessary to work in such a hurry? The reason for such extraordinary haste was the desire to "collect as

\footnotetext{
${ }_{13}$ The letter of Kondakov to Fedor I. Buslaev, June 18, 1883: I. L. KYZLASOVA, Istoriya izučeniya vizantijskogo i drevnerusskogo iskusstva v Rossii, Moscow, 1985, p. 168-169.

${ }^{14}$ M. N. MEDVEDEVA et al. Očerk istorii deyatel’nosti Imperatorskoj arkheologičeskoj komissii v 1859-1917 гг. , in E. N. Nosov, A. E. Musin, op. cit. (n. 11), p. 198-199.

${ }^{15}$ L. G. KHRUSHKOVA, Dmitrij V. Ajnalov, in S. Heid, M. Dennert, op. cit. (n. 4), S. 53-54.

${ }^{16}$ R. V. STOYANOV, Imperatorskaya arkheologičeskaya komissiya i izučenie Khersonesa Tavričeskogo, in E. N. Nosov, A. E. Musin, op. cit. (n. 11), p. 532.

${ }^{17}$ L. G. KHRUSHKOVA, Egor K. Redin, in S. Heid, M. Dennert, op. cit. (n. 4), S. 1061-1062.

${ }^{18}$ EAD., op. cit. (n. 9), S. 99-104.

${ }_{19}$ W. E. KLEINBAUER, The First Byzantine Art Historian in Russia, in Chr. Moss, R. Kiefer (eds.), Byzantine East, Latin West. Art-Historical Studies in Honor of Kurt Weitzmann, Princeton, 1995, p. 639.

${ }^{20}$ M. V. MEDVEDEVA et al., op. cit. (n. 14), p. 203-204.

${ }^{21}$ A. A. BOBRINSKIJ, Khersones Tavričeskij. Istoričeskij očerk, Sankt-Petersburg, 1905.

${ }^{22}$ L. O. GRINENKO, Kazimir N. K. Koscjuško-Valjužinič, in S. Heid, M. Dennert, op. cit. (n. 4), S. 756-757.

${ }_{23}^{2}$ I. A. ANTONOVA, K. K. Kostsyuško-Valyužinič - osnovatel' Khersonesskogo muzeya, in Nomos 28/29, 1999/200o, p. 29-40.
} 


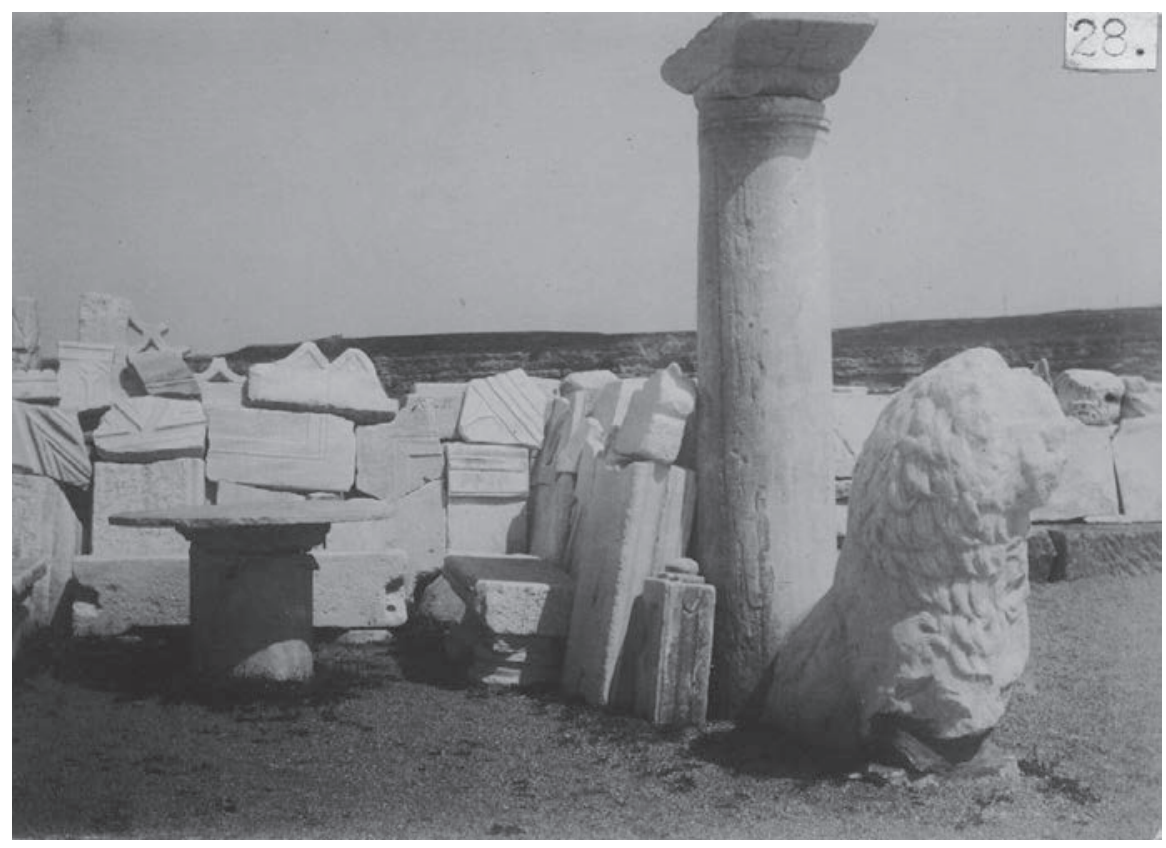

Fig. 9. Architectural marble details (The State Historical and Archaeological Museum-Preserve "Tauric Chersonese", Archives)

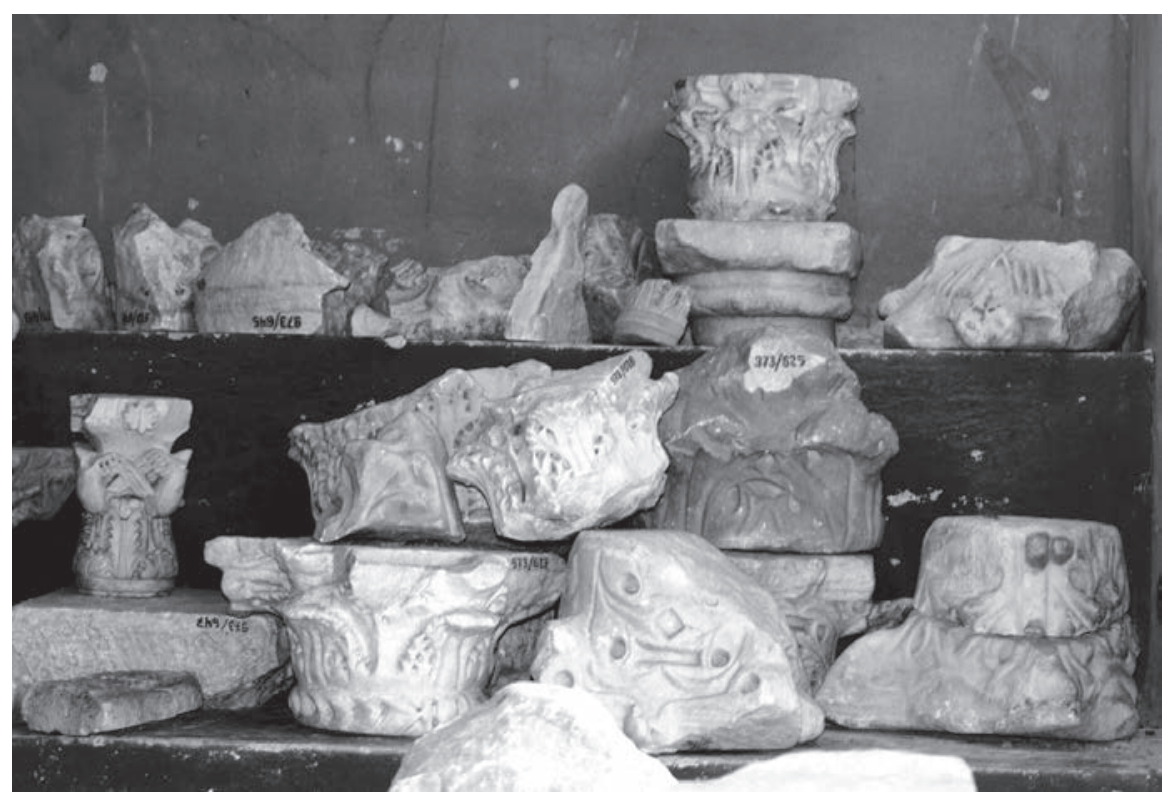

10. Architectural marble details, The State Historical and Archaeological Museum-Preserve "Tauric Chersonese" (photo L. Khrushkova) many interesting finds as possible" in order to get further funding from the Archaeological Commission ${ }^{24}$. Looking for amazing artifacts, Kostsyuško-Valyužinič and his assistants were forgetting that, in contrast to the excavations of the necropolis, in urban archaeology the most significant "artifacts" were the ruins of buildings, the heaps of architectural fragments and the piles of architectural ceramics - all the things that did not attract the attention of the Imperial museums.

That style and methods of work were not due to the personal touch of KostsyuškoValyužinič. At that time, finds served as a criterion of success. The most interesting of them were delivered to the Archaeological Commission; often they were examined by the Emperor himself, and then were distributed between the Hermitage and the Historical Museum in Moscow. The Classical artifacts were considered as "more deserving". It is widely thought that in the 1870's -1880's, Russian archaeology experienced the beginning of "a methodological turn" from "artifact-oriented" research to the study of ancient culture as an integral phenomenon 25 . But the "turn" was proceeding very slowly, and in Chersonesos not at all. Even in 1906, Bobrinskij wrote: "In recent years, my Commission has become the de facto Hermitage supplier" ${ }^{26}$.

However, the arduous activity of Kostsyuško-Valyužinič brought one undeniable benefit: in 1892 he founded the first repository of archaeological collections, which he himself called the "store of local antiquities"; the word "museum" was not suitable for this building, which looked like a barn (fig. 11).

The most essential task during excavations is the documentation of measurements. In Chersonesos the measurements of most excavated churches were performed by Martin Ivanovič Skubetov (1872-1921); he was a topographer and a draughtsman ${ }^{27}$, or, according to

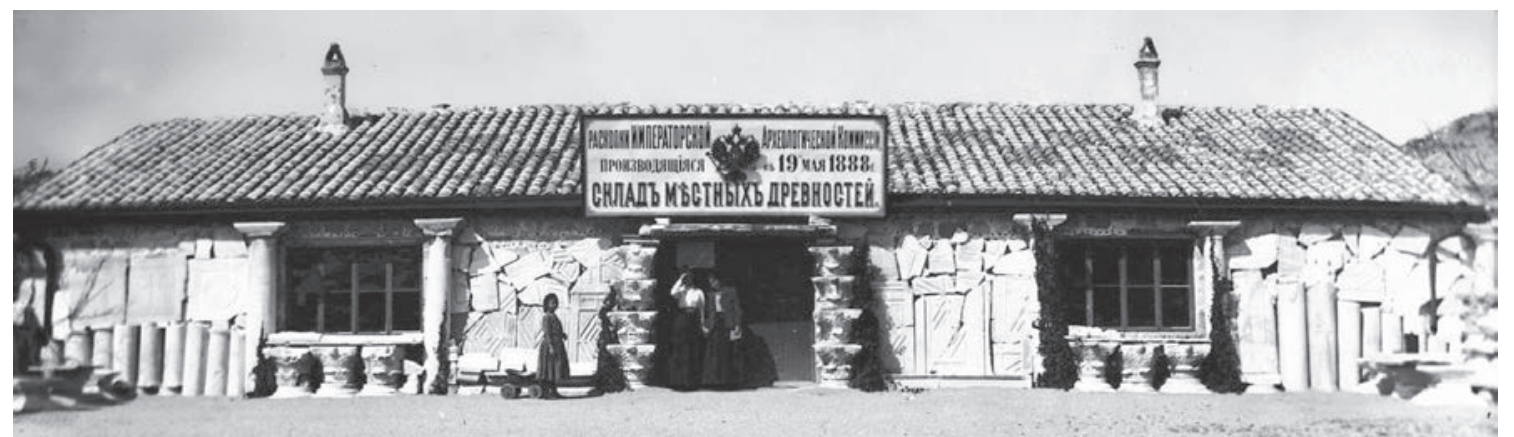

Fig. 11. "The storage of local antiquities" (The State Historical and Archaeological Museum-Preserve "Tauric Chersonese", Archives)

\footnotetext{
${ }^{24}$ R. V. STOYANOV, op. cit. (n. 16), p. 532.

${ }^{25}$ A. V. ŠAMANAEV, op. cit. (n. 7), p. 422-423.

${ }^{26}$ M. V. MEDVEDEVA et al., op. cit. (n. 14), p. 212-213.

${ }^{27}$ R. V. STOYANOV, op. cit. (n. 16), p. 545.
} 


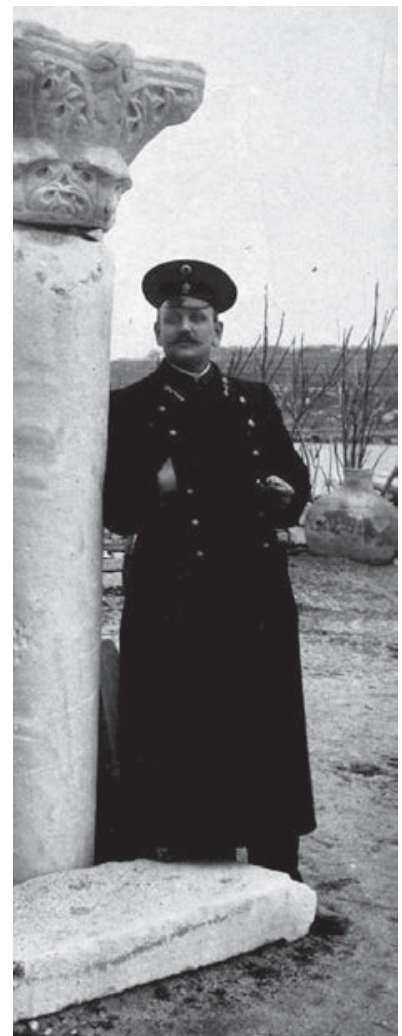

Fig. 12. Martin I. Skubetov (photo, detail: The State Historical and Archaeological Museum-Preserve

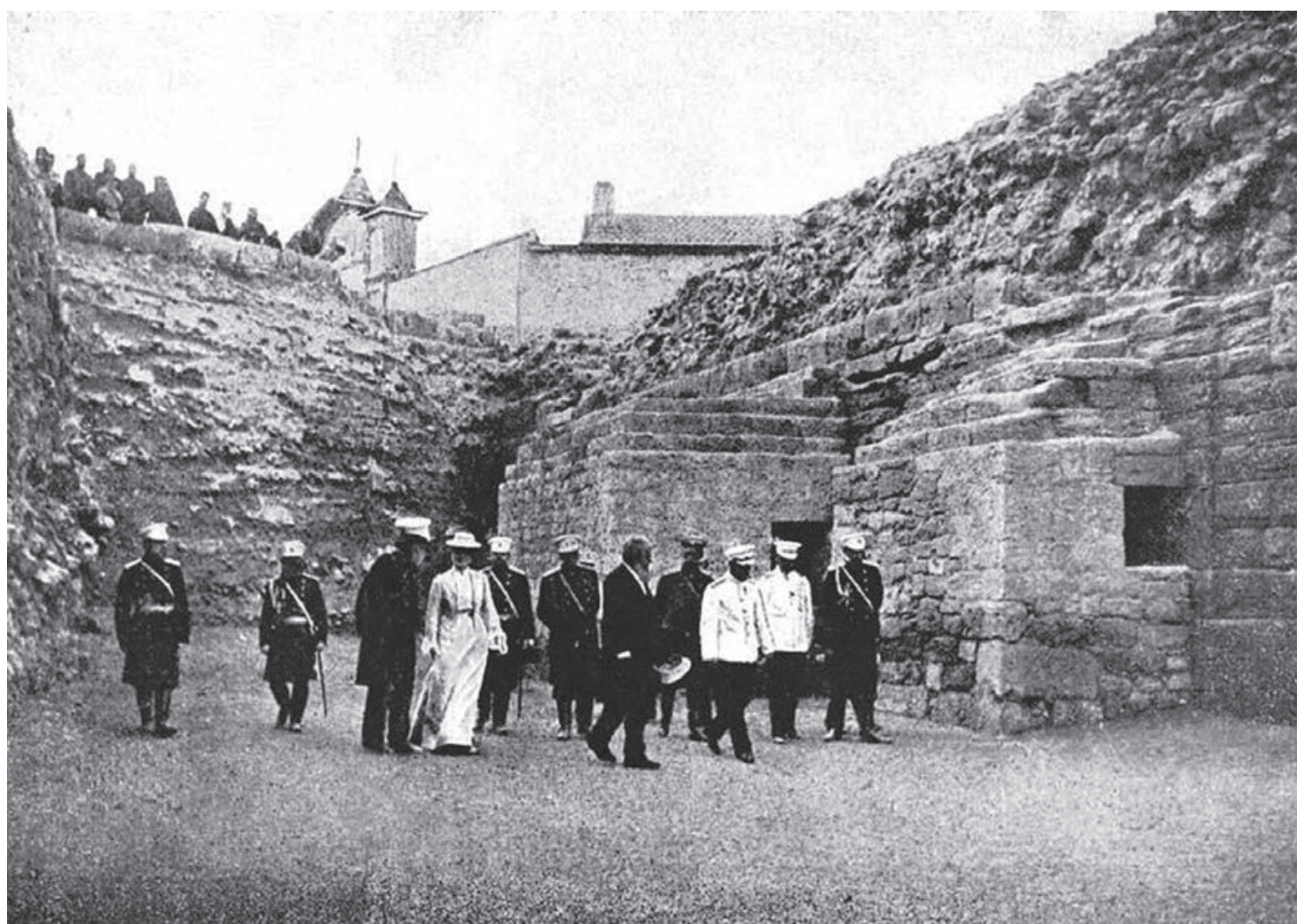

Fig. 13. Visit to Chersonese of Emperor Nicholas II, 1913 (The State Historical and Archaeological Museum-Preserve "Tauric Chersonese", Archives)

"Tauric Chersonese", Archives)

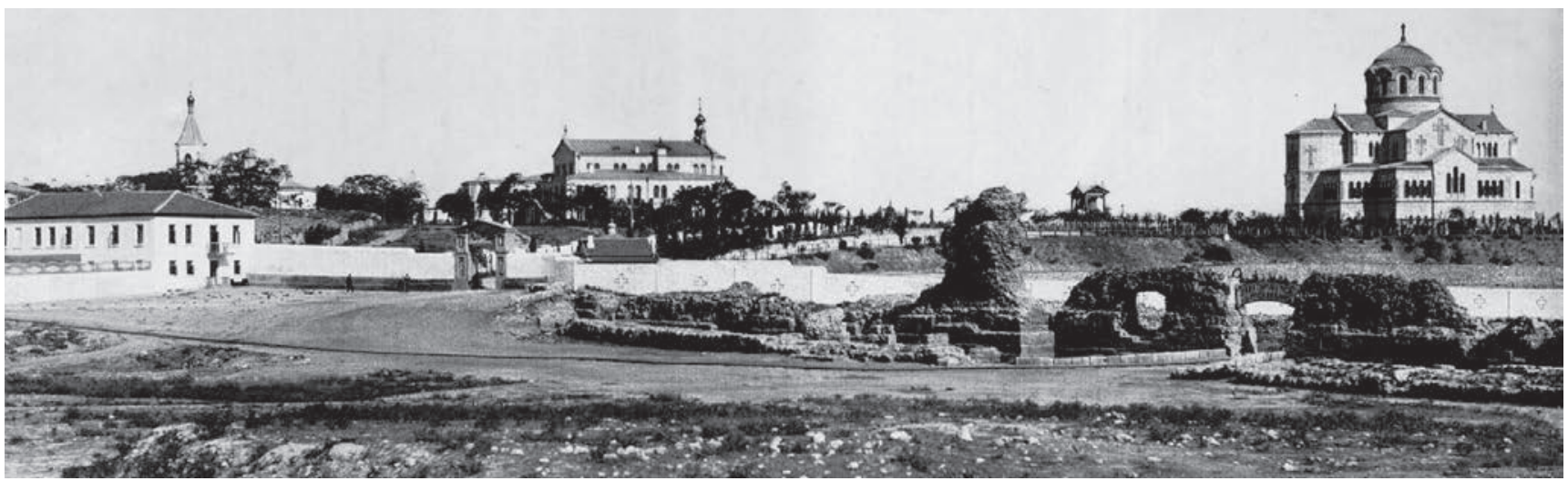

Fig. 14. St Vladimir's Church, XIXth c. (The State Historical and Archaeological Museum-Preserve "Tauric Chersonese", Archives)

other sources, - a self-taught artist ${ }^{28}$ (fig. 12). Judging by his extant drawings, Martin Ivanovič was a good draughtsman. Like Kostsjuško-Valyužinič, he was a devoted enthusiast. Unfortunately, the measurements and drawings made by Skubetov did not meet the necessary requirements. These idealized drawings with strictly parallel walls and right angles look rather like schemes. They were made on a small scale, without rendering the fragments of the masonry and other details. Most of them are just plans, the sections are very few and sketchy; they are merely the drafts of the outer contours, with no detail. There are very few measurements of the decorative elements, and there are no measurements of façades at all. There is no standard package of documents (plan, longitudinal and cross sections with views of both sides, façades, details) for any monument. In reality, the Archaeological Commission did not concern itself with such matters, and the supervisors of the excavations saw nothing wrong. The problem was not very difficult to solve: fellows of the St. Petersburg Academy of Arts travelled to Italy, to Rome, and gained there an experience of architectural measurements. Initially, the Archaeological Commission was going to invite architects from the Academy of Arts to Chersonesos, but this was not done.

In the period from 1888 until early 1919, the greater part of the Christian churches and chapels, which are known now in various parts of the town, had been already excavated. Chersonesos was visited repeatedly by august pilgrims: Alexander III had been there in 1893, Nicholas II visited the town in 1898, 1902 and 1913 (fig. 13). The result of such attention on the part of the monarchs was that the work was well-funded. Thus, in 1902, 7840 rubles were allotted to Chersonesos, while the whole territory of Russia, including Siberia (except for Olbia and Bosporos/Kerč) received 11 600 rubles $^{29}$. However, the money did not help improve the

${ }^{28}$ V. M. ZUBAR', Letopis' arkheologičeskikh issledovanij Khersonesa-Khersona i ego okrugi (1914-2005), Simferopol', 2009, p. 8-9.

${ }^{29}$ R. V. STOYANOV, op. cit. (n. 16), p. 532-533. 
quality of the excavations. Conservation works were not carried out, the ruins of buildings were growing mouldy, most of the mosaics perished.

The conflicts between the archaeologists and the Monastery of St. Vladimir form a particular chapter of the story. It is probable that laying the foundations of the monastery in 1850 virtually on the ruins of an ancient town was not a good idea to begin with (fig. 14). The Military Department also had its own interests in the area. That produced the "tangle of contradictions, which were rather insoluble in the framework of the contemporary legal system"30. Though the Archaeological Commission was in close touch with the higher powers, it was of no avail. We have the record of the conversation between Nicholas II and Bobrinskij on December 1, 1899. What did the Emperor and the chief archaeologist of Russia talk about? When the talk turned to Chersonesos, they discussed how to pronounce the family

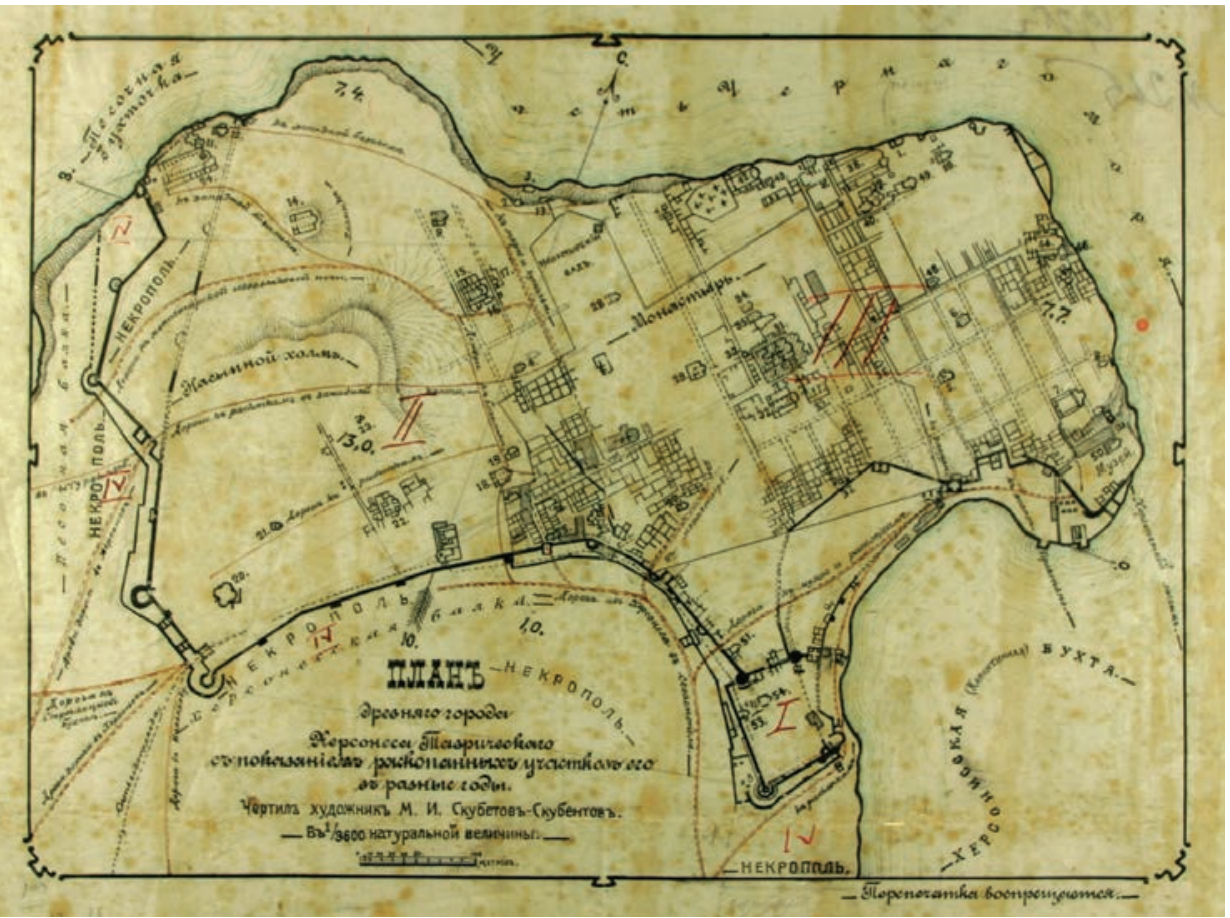

Fig. 15. Site of ancient settlement of Chersonesos, plan, M. I. Skubetov (The State Historical and Archaeological Museum-Preserve "Tauric Chersonese", Archives) name of Kostsyuško-Valyužinič and remembered that his daughters were married to Army officers. The archeology was not very important ${ }^{31}$.

A modern scholar studying the history of the Archaeological Commission, gives the following assessment to its work in Chersonesos: "There were neither adequate fixation of the findings, nor the conservation of the uncovered monuments and that inevitably led to irretrievable losses". "Unfortunately, the Archaeological Commission neglected the situation for too long", so "eventually a substantial part of the findings became worthless" ${ }^{2}$. Alas, the magnitude of "irretrievable losses" can't be overstated. If fewer monuments had been excavated then, there would now be fewer losses ${ }^{33}$.

Speaking today of the archaeologists of that period, we feel ambivalent about them. On the one hand, we admire their enthusiasm, energy, infinite devotion to their work. The real merit of Kostsyuško-Valyužinič was that he regularly published the detailed reports on the excavation, though with very inadequate documentation. And no matter how critical we may be of the humble draughtsman Skubetov, his work should be valued very highly indeed, because there are really no other and better drawings of the excavated monuments. All the plans of the Chersonesos churches published in the $2 \mathrm{O}^{\text {th }}$ century are based on these old drawings, which are so far from being perfect ${ }^{34}$ (fig. 15). On the other hand, we are astonished at the extraordinary indifference with which the Archaeological Commission and, first all, its head Bobrinskij, were observing from St. Petersburg how the most valuable archaeological material was being lost, how the ancient city was being ruined because of the lack of professional archaeologists, architects, restorers.

Another person who played a significant role in the study of Chersonesos was Alexander L. Berthier-Delagarde (18421920)35 (fig. 16). A military engineer by education, he was well-acquainted with the technique of construction; he was also an attentive observer, but he was not familiar with the scholarly publications. He did not conduct excavations, nor take measurements and he could not influence the work. His first publication was a very extensive (64 pages) paper "Antiquities of the South of Russia" 36 ; Kondakov wrote a very favorable review of this "treatise" 37 . In the much more voluminous book "On Chersonesos", Berthier-Delagarde considered only three monuments: the cruciform church at the cemetery, the walls of the city and the baptistery of the Uvarov basilica ${ }^{38}$. Berthier-Delagarde was inclined to draw definite conclusions; these were at times true, at times -

\footnotetext{
${ }_{3^{\circ}}$ A. V. ŠAMANAEV, Raskopki Khersonesa i monastyr' Sv. Vladmira: konflikt i kompromiss interesov (1895-1896 gody), in Istoričeskoe nasledie Kryma 24, Simferopol', 2009, p. 5-15.

${ }^{31}$ N. V. KRASOVSKAYA, A. I. ROMANČUK, K istorii sozdaniya Khersonesskogo muzeya, in Vizantiya v kontekste mirovoj kul'tury (Trudy Gosudarstvennogo Ermitaža, 69), Sankt-Petersburg , 2013, p. 504-505.

${ }^{32}$ R. V. STOYANOV, op. cit. (n. 16), p. 532, 546.

33 L. G. KHRUSHKOVA, op. cit. (n. 9), 3. Folge, in $R Q$ 107, 3-4, 2012, S. 232-237.

${ }^{34}$ In July 2016 I had an opportunity to work in the Archives of the State Historical and Archaeological Museum-Preserve "Tauric Chersonese" (Sevastopol'); I am very grateful for that to the Head of the Archives Tatyana A. Prokhorova. In the Skubetov archives, there are a lot of his drawings, sketches, schemes and drafts, which give an idea of his method of measurements. On the one hand, his method could not ensure accuracy, on the other hand, these materials characterize Skubetov as a very industrious and dutiful person. Probably, his sketches may be useful for modern scholars.

35 L. G. KHRUSHKOVA, Aleksandr L. Berthier-Delagarde, in S. Heid, M. Dennert, op. cit. (n. 4), S. 168-169.

${ }^{36}$ A. L. BERTHIER-DELAGARDE, Drevnosti Yužnoj Rossii. Raskopki Khersonesa (Materialy po arkheologii Rossii, 2), Sankt-Petersburg, 1893.

${ }^{37}$ N. P. KONDAKOV, op. cit. (n. 5).

$3^{38}$ A. L. BERTHIER-DELAGARDE, O Khersonese. Krestoobraznyj khram. Kreščal'nya. Krepostnaya ograda, in Izvestiya Arkheologičeskoj komissii 21, SanktPetersbutg, 1907, p. 70-87.
} 

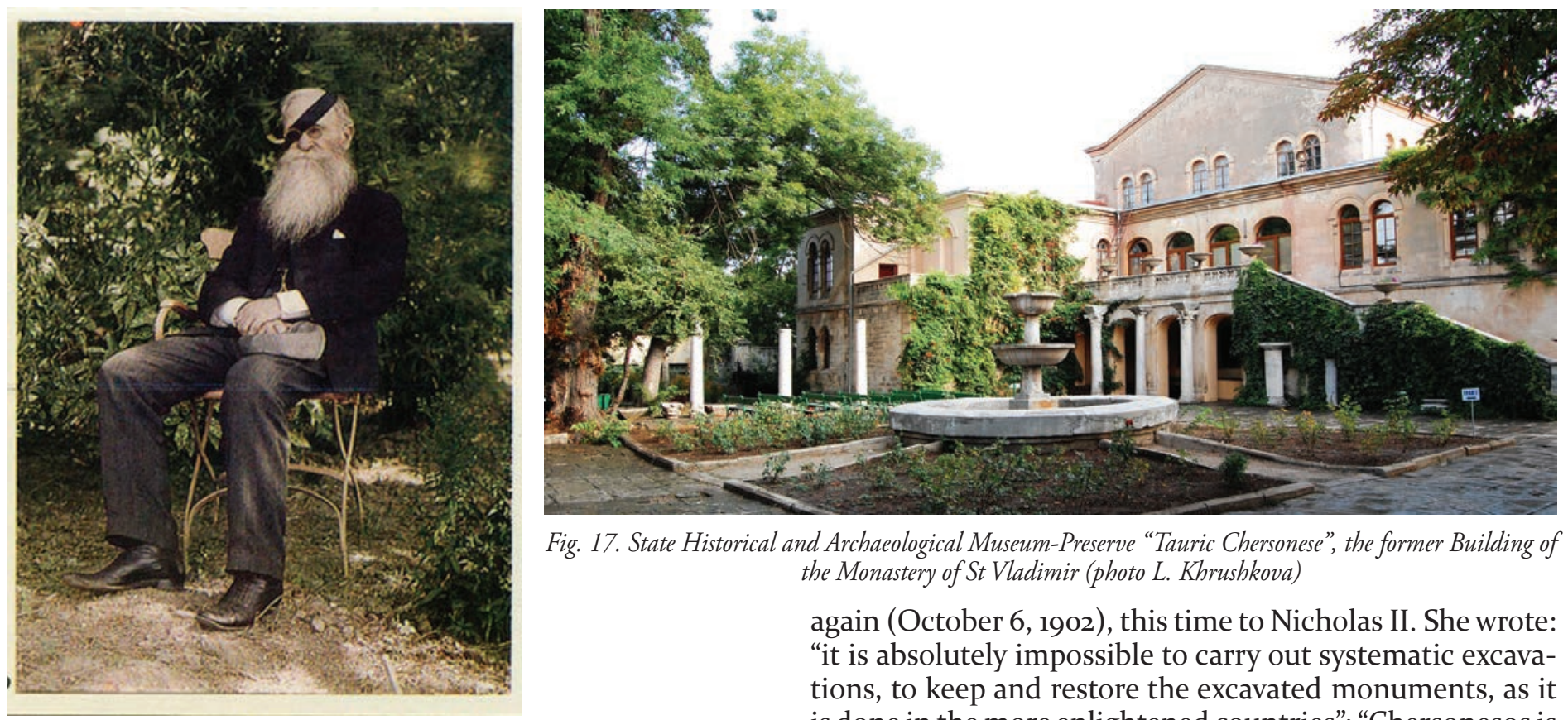

Fig. 17. State Historical and Archaeological Museum-Preserve "Tauric Chersonese", the former Building of the Monastery of St Vladimir (photo L. Khrushkova)

again (October 6, 1902), this time to Nicholas II. She wrote: "it is absolutely impossible to carry out systematic excavations, to keep and restore the excavated monuments, as it is done in the more enlightened countries"; "Chersonesos is doomed to a slow death "; the Archaeological Commission was "very indifferent (it is typical of it)" to the case. Uvarova proposed "to dissolve the monastery" and to hand over its buildings to the Museum ${ }^{41}$. But the wishes of the resolute Countess did not turn into reality soon; her propositions would be realized only under the Soviet government (fig. 17). Bobrinskij's response was plain: he accused Uvarova of "envy of the others" success" 42 .

Uvarova was well aware that the excavations in Chersonesos lacked professionalism. She had a great experience in organizing expeditions to the Caucasus, where she herself had discovered dozens of monuments of Christian architecture. She invited prominent scholars to study them, such as, for example, the academician of architecture Andrej M. Pavlinov (1852-1897) ${ }^{43}$. Uvarova aspired to repeat her successful Caucasian experience in the Crimea, and invited scholars to the excavations. She had visited Chersonesos in October 1902 and wrote to Dmitrij V. Ainalov: “... I spent two days in Chersonesos and was horrified by outrages that had been taking place there in the last years because of the negligence of the Archaeological Commission in regard to the work in its care ... you and Redin hold all the cards ... "44. Uvarova organized the publication of the series "The monuments of the Christian Chersonesos"; this title recalls Uvarova's own work "Christian monuments", which was published in the substantial series "The materials for the archaeology of the Caucasus" in 14 volumes ${ }^{45}$. However, only a few scholars responded to Uvarova's proposal. The reason for that is clear. Sergej A. Žebelev wrote to Ainalov: "It is obvious to me that all this is the campaign of 'the Uvarikha' against the Commission" ${ }^{46}$. In the eyes of Mikhail I. Rostovtsev (1870-1952)

\footnotetext{
${ }^{39}$ A. I. POMANČUK, op. cit. (n. 6), p. 29.

${ }^{40}$ R. V. STOYANOV, op. cit. (n. 16), p. 535.

${ }^{41}$ N. V. KRASOVSKAYA, A. I. ROMANČUK, op. cit. (n. 31), p. 503.

${ }^{42}$ R. V. STOYANOV, op. cit. (n. 16), p. 534-535.

${ }^{43}$ L. G. KHRUSHKOVA, op. cit. (n. 33), S. 243-245.

${ }^{44}$ I. V. IODKO, E. K. Redin: žizn'i deyatel'nost' (po materialam peterburgskikh arkhivov), in I. P. Medvedev (ed.), Mir russkoj vizantinistiki. Materialy arkhivov Sankt-Peterburga, Sankt-Petersburg, 2004, p. 337, note 135.

${ }^{45}$ P. S. UVAROVA, Khristianskie pamyatniki (Materialy po arkheologii Kavkaza, 4), Moscow, 1894.

${ }^{46}$ G. M. Bongard-Levin (ed.), Skifskij roman, Moscow, 1997, p. 399, note 1.
} 
Praskovya Sergeevna was 'the Uvarikha' too ${ }^{47}$. Indeed, Uvarova was hated by many in St. Petersburg. The offensive and coarse nickname "the Uvarikha" seems mild in comparison with the word "wolves" by which Bobrinskij called Uvarova and her fellow workers (naturally, in a private letter) ${ }^{48}$.

Fifteen years into the excavations in the Chersonesos, and still with no general work published, two students of Kondakov, Dmitrij V. Ainalov and Egor K. Redin, both of them already well-known Byzantinists, returned to the scene. Ainalov, then a professor at the Kazan University, accepted Uvarova's offer. His short book (143 pages) was the first and has the only monograph on the Byzantine architecture of Chersonesos ${ }^{49}$. The introduction to the book was published under the names of Ainalov and Redin, the two friends who had begun to study Kievan monuments together as far back as their student days. They were going to consider the Christian monuments of Chersonesos "in connection with the materials published in recent years in the field of Christian archeology and art"50. Indeed, they "held all the cards", for both had spent manyyears in Rome, Paris and other European cities and were learned in the things that were necessary for comparative study. But their plans were not realized. Neither Ainalov's next book, in which he intended to present an analysis of the Chersonesos churches and the catalog of the marbles, nor his and Redin's book were published.

Redin described Chersonesos as he saw it in June 1903, in the fifteenth year of "the brilliant epoch" of the Archaeological Commission activity in the area. "Many of them (architectural monuments - L. Kh.) were in perfect condition when they had been discovered ... And it is our Russian negligence that allowed these beautiful monuments to turn almost completely to ruin and dirt. ... When the excavated artifacts were removed, graves, vaults and stairs may have been destroyed, nobody worried about that. If only schemes, photos, descriptions had been made and published previously. But no correct schemes, no photos, only ruins. Work out by yourself, if you will, what that was. I am really astonished at such carelessness to the monuments" ${ }_{51}$. Does this picture look like the brilliant achievement imagined by Bobrinskij?

Ainalov's book was reviewed by Yakov Ivanovič Smirnov (1869-1918) ${ }^{52}$ who also visited the excavations in Chersonesos. He emphasized that the schemes published in the book were not credible because they had not been made by a specialist and that the problem of correct documentation was still awaiting a resolution. "The publication of this book does not remove the responsibility from the Archaeological Commission to publish suitably, after the editor's work has been done by a professional architect, all the remnants of all churches, which the fifteen-year-long excavations here ... draw out from the earth to the light of day ...and to the rapid destruction by nature and men" ${ }^{53}$. Smirnov's opinion deserves to be taken into consideration. Amongst the disciples of Kondakov he was the one with the greatest learning in architecture. In the 189o's, Smirnov explored monuments in many remote and obscure sites. Josef Strzygowski (18621941) used many of Smirnov's drawings and photos in his book on Asia Minor, and noted that Smirnov was the first art historian to have visited Cilicia and Lycaonia ${ }^{54}$.

Later Strzygowski also used the materials collected by Smirnov during his expeditions in Armenia55. Smirnov's student Giorgi Cubinašvili (1885-1973) ${ }^{56}$ became one of the most eminent historians of the architecture of the Transcaucasus. It is a matter of regret that Smirnov's review of Ainalov's book remained unpublished, and that no architect appeared in Chersonesos.

Chersonesos is often called "the Russian Pompeii." Uvarova wrote in a letter to Alexander III on June 5, 1887: "Command, Your Majesty, and the ancient Chersonesos will become a Russian Pompeii ..." 57 . The situation in Chersonesos has been discussed above. But how did things stand in the Italian Pompeii? In the opinion of Alla I. Romančuk, the situation was the same everywhere: "It is unlikely that during the period until the end of the $19^{\text {th }}$ century there were excavations anywhere that would satisfy us today" ${ }^{8}$. "In the late $19^{\text {th }}$ - early $20^{\text {th }}$ century, the methods of excavations in other countries were hardly any better"59.

In the archeology of Western Europe, the last third of the $19^{\text {th }}$ century was a pivotal era when the new methods of field work were formed ${ }^{60}$. The tasks of archeological research were changing: now the main aim was not the discovery of artifacts for museums, but the study of the life of past ages. The main tool of this "new archeology", as it was called, was the stratigraphic method. It was put to use firstly in Classical archeology, and then developed to be applied to the study of other periods. The leading figure at the excavations was now an architect. He was no longer a "mere measurer", a person with an auxiliary function, but the leader determining the strategy of the excavations, the scholar reading the layers as the traces of past eras.

\footnotetext{
47 The letter of Mikhail I. Rostovtsev to Sergej A. Žebelev, June 20, 1903: Pis'ma M. I. Rostovtseva S. A. Žebelevu, F. I. Uspenskomu i N. Ya. Marru (Publikatsiya I. V. Tunkinoj), in G. M. Bongard-Levin, op. cit. (n. 46), p. 398; The letter of M. I. Rostovtsev to S. A. Žebelev, July 20, 1910, in Ibid., p. 406.

${ }^{48}$ The letter of Bobrinskij to Boris V. Farmakovskij, August, 1908: D. D. ELŠIN, Imperatorskaya arkheologičeskaya komissiya i raskopki v Kieve 1908 - 1914 gg., in E. N. Nosov, A. E. Musin, op. cit. (n. 11), p. 931.

49 D. V. AINALOV, Razvaliny khramov (Pamyatniki khristianskogo Khersonesa, 1), Moscow, 1905.

${ }^{50}$ Ibid., p. VI.

${ }^{51}$ I. V. IODKO, op. cit. (n. 44), p. 337, note 135 .

${ }^{52}$ L. G. KHRUSHKOVA, Jakov I. Smirnov, in S. Heid, M. Dennert, op. cit. (n. 4), S. 1172-1173.

53 R. V. STOYANOV, op. cit. (n. 16), p. 224.

${ }^{54}$ J. STRZYGOWSKI, Kleinasien. Ein Neuland der Kunstgeschichte. Kirchenaufnahmen von J. W. Crowfoot und J. I. Smirnov, Leipzig, 1903. S. IV.

55 L. G. KHRUSHKOVA, Josef Strzygowski, Joseph Wilpert and the Russian school of Byzantine Studies, in Cahiers Archéologiques 56, Paris, 2015, p. 180-181.

${ }^{56}$ EAD., op. cit. (n. 9), 4. Folge, in RQ 108, 3-4, 2013, S. 283-286; Ibid., 5. Folge, in Id. 109, 1-2, 2014, S. 155-157.

${ }^{57}$ R. V. STOYANOV, op. cit. (n. 16), p. 526.

${ }^{58}$ A. I. ROMANČUK, Očerki istorii i arkheologii vizantijskogo Khersona, Ekaterinburg, 200o, p. 20.

${ }^{59}$ A. I. ROMANČUK, op. cit. (n. 6), p. 28.

${ }^{60}$ È. GRAN-AYMERICH, Naissance de l'archéologie moderne. 1798-1945, Paris, 1998, P. 90, 351.
} 
The architect Giacomo Boni studied the Roman Forum and the Palatine ${ }^{61}$; he created the "stratigraphic archive", the "timeline" to "read the hidden pages of history in their stratification" ${ }^{\prime 2}$. Many Russian scholars, among them Kondakov and his students such as Ainalov, Rostovtsev and Redin, and also the founder and first director of the Alexander III Museum of Fine Art in Moscow Ivan Vladimirovič Tsvetaev $(1847-1913)^{63}$ as well as many others, were well-acquainted with the Roman excavations. The excavations were accompanied by architectural conservation. The new archaeology conquered new regions. This experience was summarized by the erudite scholar Salomon Reinach (1858-1932) in his essay "The methods of archaeology" ${ }^{64}$. Reinach's name was well known in Russia, he published a French translation of the first three volumes of the series "Russian Antiquities in the monuments of art" by Ivan I. Tolstoj and Kondakov ${ }^{65}$.

A key role in the development of the precise sciencebased methods of field archeology was played by German architects and archaeologists. A major contribution to the elaboration of the stratigraphic method was made by the architect Wilhelm Dörpfeld (1853-1940). It was he who proposed the idea of architectural stratigraphy. In Troy, he amended the method of "horizontal excavations" and established the true chronology of the layers identified by Heinrich Schliemann ${ }^{66}$.

By the beginning of the $20^{\text {th }}$ century the stratigraphic method was used everywhere, from Italy to Palestine. Dörpfeld himself actively promoted it. In 1903 he organized a two-month field-trip to the sites of his excavations in Greece and Asia Minor. Invitations were sent to scholars from different countries. Russia was represented by Rostovtsev, Smirnov, and Boris V. Farmakovskij (1870-1928), who also was a student of Kondakov. From the Crimea, Vladislav Václav Škorpil (1853-1918) and Kostsyuško-Valyužinič were invited. The last declined the invitation on the pretext of being preoccupied by his work and by the prospective visit of the Emperor ${ }^{67}$.

In Pompeii, where the studies began in 1748 , the stratigraphic method was established early. Already in 1811 the study of topography and architecture was where "urban archeology" originated ${ }^{68}$. The main role was also played by an architect, François Mazois $(1783-1826)^{69}$. The next step was the foundation in 1866 by the excavations supervisor Giuseppe Fiorelli (1824-1896) of the Pompeii archaeological school. Fiorelli collaborated with the German Archaeological Institute in Rome. Wolfgang Helbig (1839-1915) published a catalog of paintings of Herculaneum and Pompeii ${ }^{7}$. In 1874 Helbig lectured in Rome on the "archeology of art" (Kunstarchäologie); his lections were attended by young Kondakov during his first visit to the Eternal City ${ }^{71}$. Years later, Rostovtsev, who had just completed his education, was attending the lectures of August Mau (1840-1909), who delivered them at the ruins of Pompeii ${ }^{72}$. These lessons were not lost. It was Rostovtsev who promoted in Russia the exact, "European" methods of excavation. He wrote to Fedor Ivanovič Uspenskij $\left(1845^{-1928}\right)^{73}$, the Head of the Russian Archaeological Institute in Constantinople, about the candidacy for the post of the archaeologist who would carry out the excavations in the Balkans in the summer of 1912: "I don't know of a quite suitable candidate, but there are a few persons that match not the ideal but the average grade of European researchers" 74 . Rostovtsev's essay on the paintings of the ancient crypts in Kerč and in Chersonesos is one of the best works in his legacy ${ }^{75}$.

With Christian and Byzantine monuments, the stratigraphic method was first applied where medieval buildings were situated either on the remains of antique ones, or next to them. This was the case, above all, in Rome. Having established the stratigraphic method in Pompeii, Giuseppe Fiorelli is invited to Rome, where he excavates the Forum. His work would be carried on by architect and archaeologist Amedeo Rodolfo Lanciani (1845-1929) ${ }^{76}$. Giacomo Boni continued the study of the S. Maria Antiqua ${ }^{77}$. In Greece one of the pioneers was Panayotis Kavvadias (1850-1928). Kavvadias began to apply the methods of German archaeologists in his excavations and extended this practice to the Byzantine monuments ${ }^{78}$. The Society of Christian archeology was founded in 1884 and launched a broad project of study and restoration of Byzantine architectural monuments ${ }^{79}$.

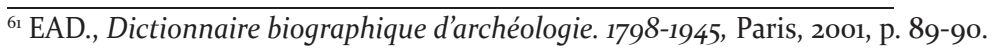

${ }^{62}$ È. GRAN-AYMERICH, op. cit. (n. 6o), p. 355.

${ }^{63}$ L. G. KHRUSHKOVA, Ivan V. Cvetaev, in S. Heid, M. Dennert, op. cit. (n. 4), S. 349-350.

${ }^{64}$ S. REINACH, Les méthodes en archéologie, in Revue du mois, Paris, 1911, p. 279-292.

${ }^{65}$ N. P. KONDAKOV, I. I. TOLSTOI, S. REINACH, Antiquités de la Russie méridionale, 1-2, Paris, 1891-1893.

${ }^{66}$ È. GRAN-AYMERICH, op. cit. (n. 61), p. 226-228.

${ }^{67}$ M. V. MEDVEDEVA et al., op. cit. (n. 14), p. 199-200.

${ }^{68}$ È. GRAN-AYMERICH, op. cit. (n. 6o), p. 25-26, 34, 41-42.

${ }^{69}$ F. MAZOIS, Les ruines de Pompéi, 4 Voll., Paris, 1813-1838.

${ }^{70}$ È. GRAN-AYMERICH, op. cit. (n. 6o), p. 163-164; EAD., op. cit. (n. 61), p. 331-332.

${ }^{71}$ L. G. KHRUSHKOVA, Khristianskaya arkheologiya $v$ Zapadnoj Evrope i russkaya škola vizantinistiki, in Učenye Zapiski Rossijskogo pravoslavnogo universiteta ap. Ioanna Bogoslova 5, Moscow, 2000, p. 229-230.

${ }^{72} \mathrm{~A}$. MAU, Geschichte der dekorativen Wandmalerei in Pompeji, Berlin, 1882.

${ }^{73}$ L. G. KHRUSHKOVA, Fedor I. Uspenskij, in S. Heid, M. Dennert, op. cit. (n. 4), S. 1259-126o.

${ }^{74}$ Letter to Uspensky, December 4, 1911: G. M. Bongard-Levin (ed.), op. cit. (n. 46), p. 412.

75 I. M. ROSTOVTSEFF, La peinture décorative antique en Rissie Méridionale, en 2 vol., Sankt-Petersburg, 1913-1914 (Paris, 2003-2004) (Mémoires de l'Académie des Inscriptions et Belles-Lettres, 28).

${ }^{76}$ D. PALOMBI, Amedeo R. G. F. Lanciani, in S. Heid, M. Dennert, op. cit. (n. 4), S. $782-784$.

77 A. PAIBENI, Giacomo Boni, in S. Heid, M. Dennert, op. cit. (n. 4), S. 207-208.

${ }^{78}$ È. GRAN-AYMERICH, op. cit. (n. 61), p. 374-375.

79 E. CHALKIA, Geschichte der Christlichen Archäologie in Griechenland - ein Überblick, in RQ 105, 1-2, 2010, S. $129-142$.
} 
In the coastal region to the south-west of the Crimea, in particular in Varna (Odessos) and its vicinity, the period of the late $19^{\text {th }}$ century - early $20^{\text {th }}$ century saw a rapid progressive development in the archaeological study of early Christian and Medieval monuments of architecture ${ }^{80}$. A prominent figure in this development was Karel V. Škorpil $\left(1859^{-1944}\right)^{81}$, the brother of the well-known Crimean archaeologist Vladislav V. Škorpil. Scholars from the Russian Archaeological Institute in Constantinople, in collaboration with Bulgarian archaeologists, successfully explored ancient Bulgarian towns ${ }^{82}$.

By some unhappy confluence of factors, neither the innovations in the methods of archaeological research affected Chersonesos; here nothing changed. The excavations continued to be carried out only by Kostsyuško-Valyužinič (until his death 1907), his reports continued to be well-received in St. Petersburg. Uvarova's vigorous, but short-lived efforts had no effect.

\section{THE STRATIGRAPHIC METHOD IN RUSSIA: KIEV}

There is no doubt that the activities of the Archaeological Commission were not without success. One of its obvious achievements was the excavation of two churches in Kiev: the Church of the Tithe and the St. Sophia. The work was carried out in 1908-1911 by Boris Farmakovskij and Kievan architect and artist Dmitrij Vasilyevič Mileev (1878-1914). Farmakovskij divided the site into big $(5 \times 5 \mathrm{~m})$ squares. "Each occupation layer was thoroughly examined separately" and "each one was drawn as accurately as if it were an architectural monument .... Farmakovskij emphasized an "unprecedented in our country thoroughness and precision" with which Mileev "sketched and took photos of the smallest details of layers of the soil" ${ }^{3}$. The archaeologists were consistently committed to the practice of "layer-bylayer study of each occupation level". In the view of modern scholars, in Kiev, "Russian archaeologists for the first time undertook a truly scholarly study of the occupation layers of a medieval town" ${ }^{\prime 4}$.

The technique used by Farmakovskij and Mileev were similar to the one developed earlier during excavations in Greece, Asia Minor, Pompeii and Rome. There were no essential differences between the two, they varied only in certain details. Farmakovsky was familiar with the Western European experience, in particular with the Classic excavations of Dörpfeld. An important shared feature of the Russian and the Western methods is the extension of the methodology from the archeology of the Classical era to the Medieval period. Farmakovsky developed his own methods in Olbia and then applied them to medieval Kiev. The Kievan excavations differed dramatically from the excavations in
Chersonesos, but there was also some similarity: in Kiev, as in Chersonesos, "the air was filled with intrigue"

\section{THE SOVIET EXPERIENCE AND THE EUROPEAN CONTEXT}

More than half a century after the appearance of Ainalov's book, a new work on the Byzantine architecture of Chersonesos was published, namely, two chapters in the book by Anatolij Leopoldovič Yakobson (1906-1984) ${ }^{86}$ (fig. 18) on Early Medieval Chersonesos ${ }^{87}$. It is the only work in which the architecture of the churches, their marble and mosaic décor are considered as a whole. Establishing the chronology of the basilicas of Chersonesos, Yakobson cautiously attributed them to a wide period, dating them to the $5^{\text {th }}-6^{\text {th }}$ centuries, and some to the $7^{\text {th }}$ century. As for the graphics, Yakobson noted that in Ainalov's book "the drawings are schematic, inaccurate, and often, as we were to discover while at the sites, wrong" ${ }^{\prime 8}$. But unfortunately

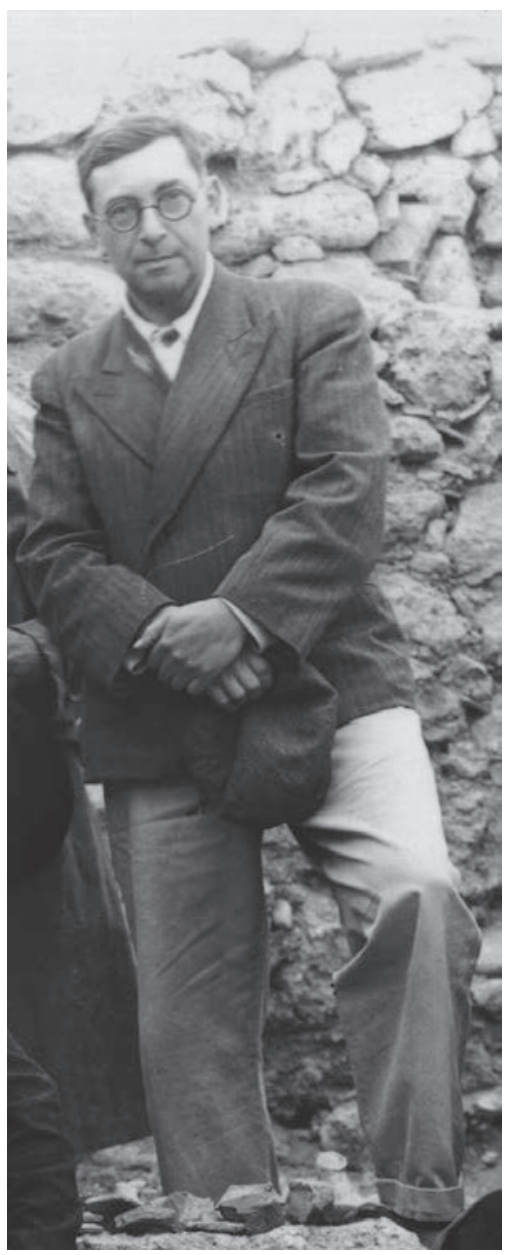

Fig. 18. A. L. Yakobson (photo, detail: The State Historical and Archaeological Museum-Preserve "Tauric Chersonese", Archives)

\footnotetext{
${ }^{80}$ H. PRESHLENOV, Frühchrisrliche Archäologie an der bulgarischen Schwarzmeerküste (1878-2008), in RQ 105, 1-2, 2010, S. 78-105.

${ }^{81}$ H. PRESHLENOV, Karel Václav Škorpil, in S. Heid, M. Dennert, op. cit. (n. 4), S. 1171.

${ }_{82}$ Ž. VYŽAROVA, Ruskite učeni i bylgarsite starini, Sofiya, 1960, p. 322-335; E. YU. BASARGINA, Russkij arkheologičeskij institut v Konstantinopole, SanktPetersburg, 1999, p. 51-55.

${ }_{3}^{3}$ D. D. ELŠIN, op. cit. (n. 48), p. 918-920, 924.

${ }^{84}$ IBID., p. 935.

${ }^{85}$ IBID., p. 929

${ }^{86}$ L. G. KHRUSHKOVA, op. cit. (n. 9), 5. Folge, in RQ 109, 1-2, 2014, S. 142, 153.

${ }^{87}$ A. L. YAKOBSON, Rannesrednevekovyj Khersones (Materialy i issledovaniya po arkheologii SSSR, 63), Moscow-Leningrad, p. 125-247.

${ }^{88}$ IBID., p. 128.
} 
there are no other drawings. The drawings in Yakobson's book have a different graphic design in black and have been partly modified. Yakobson's conclusions generally keep their relevance, though they may be clarified, while to his observations much information may be added. The reason for this is his successful using of the comparative method.

This method was surely and universally accepted in the various fields of humanities in Western Europe and Russia. Historians of art and architecture borrowed it from philologists. In Russia its use was pioneered by Fedor I. Buslaev $(1818-1898)^{89}$. He taught it to his students, including Kondakov, who, in turn, taught it to his own disciples ${ }^{\circ}$. The comparative method had a staunch supporter and active promoter in the person of Josef Strzygowski (1862-1941) ${ }^{91}$, who expanded it to the study of architecture. In his voluminous preface to the French translation of Strzygowski's book on Syria, Gabriel Millet (1867-1953) highly appreciated the comparative method itself, but noticed, that the Syrian art was presented in Strzygowski's book as at the broken glass $^{92}$. The famous Viennese scholar incorrectly dated two key monuments - the Mshatta reliefs and the Antioch Chalice, and as a result the entire picture was distorted. Another well-known Byzantine scholar, Louis Bréhier (1868-1951), in a review of the same book, highlighted that the comparative method had to be used in conjunction with other independent evidence: the combination helped establish a reliable chronology of the monuments under consideration ${ }^{93}$. Yakobson used the comparative method systematically. The main characteristics of his approach were discretion and moderation, the ability to refrain from excess. Establishing the sequence of the development of some architectural phenomenon or some element of sculptural decoration, he relied on the already established independent datings. Thus, determining the date of the construction of Uvarov's basilica, Yakobson rightly pointed out as a key analogy the Basilica of St. John the Baptist of the Studion Monastery in Constantinople, which dates from 453 (when Yakobson worked, it was thought to have been built in 463).

In the 189o's Kondakov expressed his opinion about the objectives and methods of studying Byzantine monuments in Chersonesos. "The mutual benefit gained from setting the local archaeological research on the foundation of general art history is so obvious and so great, that any such study takes a particular significance"94. The work of Yakobson, who set a group of local monuments in the general historical and architectural context, is an example of this type of research. He classified the Early Byzantine basilicas of Chersonesos as belonging to the "Hellenistic type"; the most typical and characteristic representation of this type is Uvarov's basilica. This conclusion, which was a kind of innovation in Yakobson's time, seems almost trivial today, for the same classification was offered by Richard Krautheimer in his well-known compendium of Early Christian and Byzantine architecture ${ }^{95}$.

Descriptions and conclusions in Yakobson's book are very similar to the ones in Krautheimer's and this is not difficult to explain. Both researchers applied the same comparative method and both used for comparison the broad range of materials from different regions of the Mediterranean. But it is worth noticing that Yakobson's book was published several years earlier than Krautheimer's compendium. In his discussion of Chersonesos, Yakobson really reconstructed the general picture of the development of Early Byzantine architecture, even if in a sketchy, concise manner. It was the first attempt at such a reconstruction in Russian historiography. The first summarizing survey of the history of Byzantine architecture appeared in Russia only in 1966; it was a part of the third volume of the "General History of Architecture" by Nikolaj Ivanovič Brunov (1898-1971) ${ }^{96}$.

Yakobson could have relied on only one general work, the book "The Greek School in Byzantine Architecture" by Gabriel Millet ${ }^{97}$, which was, in essence, the first overview of the history of Byzantine architecture. Large-scale excavations of the architectural monuments began later, in the years between the two World Wars, and became more extensive in the post-war period. It was this new material that Yakobson used for comparison with the churches of Chersonesos.

He borrowed the terminology of Millet, which is used to this day. It is worth noticing that there are some differences between the terms used in the books by Yakobson and Millet on the one hand, and in Krautheimer's compendium on the other. Millet had suggested the existence of two basic types of the Byzantine basilica: the "Hellenistic" and the "Eastern". Yakobson described the basilicas of Chersonesos as belonging to the "Hellenistic type". Millet contrasted the "Hellenistic type" with the "Eastern type". The "Hellenistic type" is common in the coastal urban centers of the Mediterranean, while the "Eastern type" is seen in the hinterland and peripheral areas. Although this classification is rather basic and does not reflect the whole diversity of local variants, it retains its value.

Krautheimer's terminology is different, however, one might see in its background some of Millet's ideas and classification. In Millet's time, the typological approach dominated, so he classified basilicas by "types". Krautheimer was a passionate advocate of the stylistic approach, so he applied the concept of "style", but in essence his classification was similar to Millet's. Krautheimer demarcated large regions in which various "styles" dominated. His book is concerned with the entire Mediterranean world, so we have three regions. The first included Rome and the Wes-

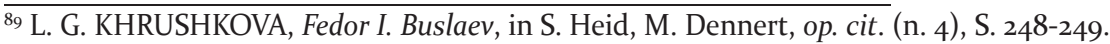

${ }^{90}$ L. G. KHRUSHKOVA, Nikodim Pavlovič Kondakov: novaya monografiya, in Vizantiya v kontekste mirovoj kul'tury (Trudy Gos. Ermitaža,74), Sankt-Petersburg, 2015, p. 468, 474-475.

${ }^{91}$ A. ZÄH, Josef Strzygowski als Initiator der christlich-kunsthistorischen Orientforschung und Visionär der Kunstwissenschaft, in RQ 107, 3-4, 2012, S. $249-292$. ${ }_{92}$ G. MILLET, Étude préliminaire, in J. Strzygowski, L'ancien art chrétien de Syrie, Paris, 1936, p. II, XVII, XXXV, XLV-XLVI.

${ }_{93}$ L. BRÉHIER, Book review: J. Strzygowski, L'ancien art chrétien de Syrie, Paris, 1936, in Journal des Savants, sept.-oct. 1938, p. 193-202, nov.-déc. 1938, p. 241-248.

${ }^{94}$ N. P. KONDAKOV, op. cit. (n. 5), p. 396.

${ }_{95}$ R. KRAUTHEIMER, Early Christian and Byzantine Architecture, Harmondsworth, Middlesex, England, 1965 (the first ed.).

${ }_{96}^{6}$ N. I. BRUNOV, Arkhitektura Vizantii, in Vseobščaya istoriya arkhitektury 3, Moscow, 1966, p. 16-16o.

${ }_{97}$ G. MILLET, L'école grecque dans l'architecture byzantine (Bibliothèque de l'École des Hautes Études, 226), Paris, 1916.
} 
tern area (it is absent in Millet's classification). The second great region, dominated by Greek and Hellenistic culture, included Constantinople as its main center and also the Aegean coastal areas, Thrace, Macedonia, the south of the Balkans, Greece, the coastal areas of Asia Minor, the Greek Islands, the coastal urban centers of Syria, Palestine, Egypt and Cyrenaica. The Crimea as well as the whole Black Sea region belongs to this second region. The second region in Krautheimer's scheme match the "Hellenistic type" in Millet's terms. The third region is the East, the inner areas of Asia Minor and the Middle East. Millet associated his "Eastern type" with this area. This classification refers to the period from the end of the $4^{\text {th }}$ to the $6^{\text {th }}$ century ${ }^{98}$. Krautheimer cites as a typical example a $5^{\text {th }}$ century basilica from the Aegean region: the Acheiropoietos basilica in Thessaloniki, which dates from c. 47099. It closely resembles Uvarov's basilica, not only in the basic characteristics, but also in details.

Yakobson summed up the results of his many years of research in two books on the laws governing the development of Early Medieval and Medieval architecture ${ }^{100}$. Yakobson's and Krautheimer's approaches resemble each other. Both scholars draw on the idea of the evolution, the progressive development of Medieval architecture, which was based on "its very rich ancient legacy, the great Classic tradition"101. The affinity of the ideas of the two scholars may be explained by similarity, in a way, of their background. Krautheimer represented the German school of art history, founded on the ideas of Heinrich Wölfflin, who, in turn, rested upon the general theoretical speculations of Hegel. Yakobson's concept of progressive development derived from Marxism, also based on Hegel's ideas. Yakobson's and Krautheimer's works had another common feature: both scholars were interested in those aspects of the social, political and cultural history of society, which were mirrored in the construction activities. Attention to such issues is inherent in the Marxist approach. As for Krautheimer, his personal interest in the political aspects of the history of the architecture of Late Antiquity became even more profound in the later period of his long and fruitful life $\mathrm{e}^{102}$.

Yakobson's book on Early Medieval Chersonesos laid a firm foundation for the continuation of architectural studies in the Crimea. Nonetheless, by the end of the Soviet period, there were no essential achievements in this field: the chronology of basilicas had not been established, the marbles had not been published, the relationship between the liturgy and the architecture had not been studied, and finally, there still were no "valid architectural measurements of the basilicas"103.

Along with the evolutionary approach to the study of the history of architecture, which was applied by Yakobson, another trend of research was successfully developing in Russia, that is architectural archeology. It originated from the collaborative works in Smolensk of Nikolaj Nikolaevič Voronin (1904-1976) and Pavel Alexandrovič Rappoport (1913-1988). Later the works of Rappoport and his students established the new attitude in the Russian tradition of studying Old Russian architecture ${ }^{104}$. This interdisciplinary approach combines the stratigraphic methods of field archeology with the accurate measurements of architectural monuments and the analysis of visual and written sources ${ }^{105}$. This approach was applied not only to the study of Old Russian architecture, but also to the research in some regions of the Caucasus, in Abkhazia, for example. In essence, Rappoport reproduced, in a different historical situation and with other material, the attitudes and achievements of the German architects and archaeologists working in Greece and Asia Minor in the last third of $19^{\text {th }}$ century. Thus, Russian architectural archeology emphasized once again the close relationship between Old Russian stone architecture and the traditions of Antiquity inherited through Byzantium. The achievements of Russian architectural archeology were noted abroad. Cyril Mango points out in his preface to the English translation of Rappoport's book on the Old Russian building technique that this topic has been studied better in connection with Old Russian architecture than in relation to Byzantine monuments ${ }^{106}$.

In Western Europe, the development of architectural and archaeological studies proceeded in a different fashion. The methods of stratigraphic archeology have been widely practiced in the study of ecclesiastical architecture during the last 20-25 years, in connection with the tasks of restoration, primarily, in the Mediterranean countries - Spain, France and especially Italy. In Italy and Spain the journals titled "Archaeology of Architecture" are published ${ }^{107}$. In France, there is a preference for the term "archeology of building". In the 1980's in France there was extensive discussion of what features make the "archeology of building" an "independent branch of archeology" and a new discipline. The situation changed in the 1990's, and in the 200o's the first generalizing works were published, evidence of the "maturity" of the discipline ${ }^{108}$. In the 1980's, the archeology of architecture reached Spain from Italy. In the 1990's the publication of theoretical works on the methods of archeological study

\footnotetext{
$9^{8}$ R. KRAUTHEIMER, op. cit. (n. 95), 1975, p. 100-102.

99 IBID., p. 105-108.

${ }^{100}$ A. L. YAKOBSON, Zakonomernosti v razvitii rannesrednevekovoj arkhitektury, Leningrad, 1983; ID., Zakonomernosti v razvitii srednevekovoj arkhitektury IX-XVvv. Leningrad, 1987.

${ }^{101}$ ID., op. cit. (n. 100, 1983), p. 5.

${ }^{102}$ M. DENNERT, Richard Krautheimer, in S. Heid, M. Dennert, op. cit. (n. 4), S. 761-764.

${ }^{103}$ S. A. BELYAEV, Baziliki Khersonesa (itogi, problemy i zadači ikh izučeniya), in VV 50, Moscow, 1989, p. 171-181.

104 P. A. RAPPOPORT, O metodike izučeniya drevnerusskogo zodčestva, in Sovetskaya Arkheologiya 3, Moscow, 1988, p.118-129; ID., Russkaya arkhitektura XXIII vv. (Svod arkheologičeskikh istočnikov, E 1-47), Leningrad, 1983; ID., Drevnerusskaya arkhitektura, Sankt-Petersburg, 1993; ID., Stroitel’noe proizvodstvo Drevnej Rusi X-XIII vv., Sankt-Petersburg, 1994.

${ }^{105}$ L. G. KHRUSHKOVA, op. cit. (n. 86), S. 147-149.

${ }^{106}$ C. MANGO, Foreword, in P. A. RAPPOPORT, Building the Churches of Kievan Russia, London, 1995, p. 14

${ }^{107}$ M. VALENTI, M.-A. CAUSARANO, Dall'Archeologia dell'architettura all'Archeologia di una città. Il caso di Siena, in Archeologia dell'Architettura 15,2010 , p. 131-150; A. AZKARATE GARAI-OLAUN, Archeologia dell'Architettura in Spagna, in Ibid., p. 17-28.

${ }^{108}$ N. REVEYRON, L'archéologie du bâti en France, in Ibid., p. 29-46.
} 
of architectural monuments signified the "official" establishment of architectural archeology in that country ${ }^{109}$. European researchers emphasize the interdisciplinary character of the "archeology of architecture", which implies the collaborative efforts of architects, restorers, architectural historians and archaeologists. Yet another feature of this relatively young movement in Europe is its wide geography, from Spain to Jordan ${ }^{110}$.

But let us go back to Chersonesos. What impact did the experience of domestic architectural archeology had on the situation there? In Chersonesos the methods of architectural archeology were not used. Unfortunately, it was a return of the situation in the late $19^{\text {th }}$ century: methods already available to archeologists, both in Russia and in the West, were lost on the researchers of Chersonesos.

\section{CHERSONESOS IN THE POST-SOVIET PERIOD}

During the last quarter of the $2 \mathrm{O}^{\text {th }}$ century, studies of Christian history and Christian archeology underwent extensive development in the Crimea ${ }^{\mathrm{m}}$. But in the various books and articles on the topic, we don't really see an analysis of architecture and architectural decoration. Surveys of the monuments are included in the publications on the Byzantine Chersonesos-Cherson; the authors seek to establish the chronology of the monuments on the basis of some general considerations. In one case, the date of construction of the Early Byzantine churches of Chersonesos is determined on the basis of "arithmetic calculations", "elementary logic" and "logical patterns" example, it was impossible that so many churches should have been built in Chersonesos in the course of only 200 years, so the date of their construction should be "distributed" over a longer period.

But how do such "arithmetic calculations" fit the facts? In Rome all the major Early Christian basilicas were built during the $4^{\text {th }}$ century. In Constantinople a series of large domed churches dates from several decades of the $6^{\text {th }}$ century, from the reign of Justinian I or a short time before it. Churches of Ravenna were built in the $5^{\text {th }}-6^{\text {th }}$ centuries. The situation was similar in Diocletianopolis (modern Hissar) in Bulgaria, where about a dozen basilicas were built in the $5^{\text {th }}-6^{\text {th }}$ centuries. In Gerash (Gerasa) in the north of Jordan, archaeologists discovered seventeen Early Byzantine churches. Gilbert Dagron notes that in some towns the number of churches exceeds the number of inhabitants; obviously the construction of churches didn't just answer the local religious needs"13. The religious life of a town can't be understood in the terms of arithmetical calculations; it was influenced by a complex combination of different factors.

The hypothesis of an "architectural boom", which was put forward by Sergej B. Soročan is yet another general idea,

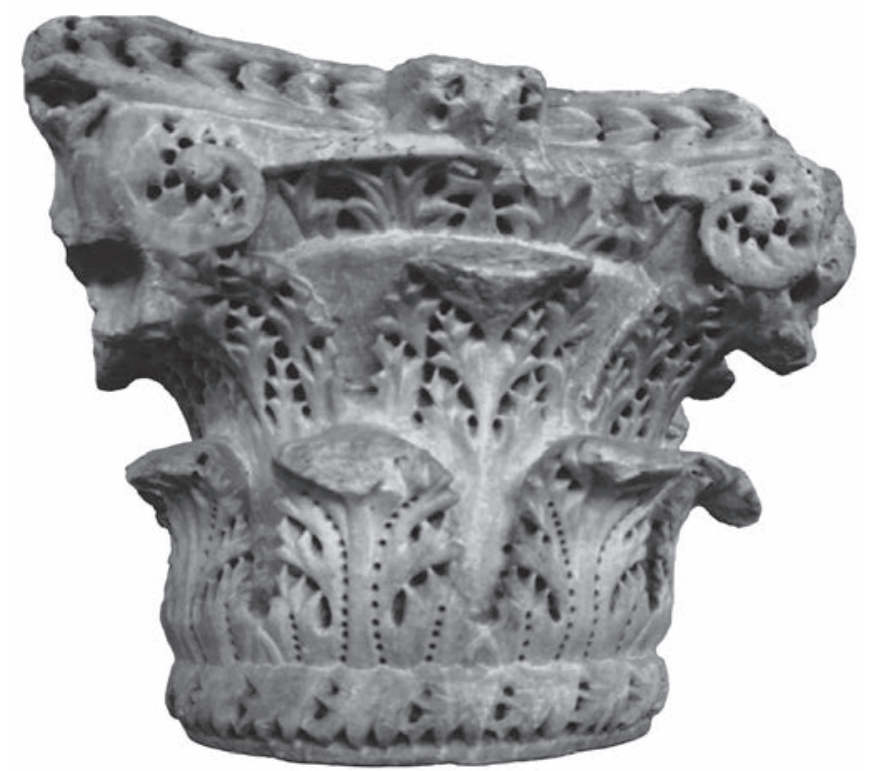

Fig. 19. Capital with fine-toothed acanthus leaves (photo L. Khrushkova)

from which the chronology of the churches of Chersonesos has been deduced. All of them are dated to the end of the $6^{\text {th }}$ - the first half or and even the third quarter of the $7^{\text {th }}$ century. This is a repetition of the old dating by BerthierDelagarde $^{114}$, but without any analysis of the monuments themselves. The recent archaeological evidence does not support the idea of a "boom". The existence of hundreds of marble architectural details, which were brought from Prokonnessos to Chersonesos before and during the period of Justinian, also contradicts the supposition about the "architectural boom" at the end of the $6^{\text {th }}$ - the first half of the $7^{\text {th }}$ century ${ }^{15}$ (fig. 19).

Yet another way to establish the chronology of the monuments involves an unusual periodization of Byzantine history, one that cardinally disagrees with the standard one. In the book by Soročan, the Byzantine period in Chersonesos begins in the second half of the $6^{\text {th }}$ century, and thus the whole pre-Justinian and most of the Justinian epoch are excluded from the domain of Byzantine history. Under this scheme, all the Early Byzantine basilicas of Chersonesos are ipso facto from no earlier than the middle of the $6^{\text {th }}$ century. The strangeness of this periodization has already been noted ${ }^{116}$.

The history of Christianity in Chersonesos as reflected in the history of religious monuments was addressed in the thesis of Irina A. Zavadskaya. The author tries to establish the chronology of the churches via the study of the excavated archaeological. She describes her approach as follows. "In the absence of written evidence, the absolute chronology of the construction of the ecclesiastical buildings in Chersonesos can be established only on the basis of the bulk

${ }^{109}$ A. AZKARATE GARAI-OLAUN, op. cit. (n. 107), p. 17-18.

${ }^{110}$ G. P. BROGIOLO, Introduzione, in Ibid., 2010, p.11; C. TOSCO, Interpretare le architetture: il dialogo tra l'archeologia e la storia, in Ibid., p. 211.

${ }^{m}$ L. G. KHRUSHKOVA, op. cit. (n. 9), 6. Folge, in RQ, 110, 1-2, S. 126-130.

${ }^{112}$ A. I. ROMANČUK, op. cit. (n. 6), p. 331-344.

${ }^{113}$ G. DAGRON, Le christianisme dans la ville byzantine, in DOP 31, Washington, 1977, p. 6.

${ }^{114}$ S. B. SOROČAN, Vizantijskij Kherson (vtoraya polovina VI - pervaya polovina Xv.). Očerki istorii i kul'tury 2, Khar'kov, 2005, p. 716, 768.

${ }^{115}$ L. G. KHRUSHKOVA, Prokonnesskij mramor v Khersonese Tavričeskom: kapiteli s tonkim zubčatym akanfom, in VV 70, Moscow, 2011, p. 314-316; EAD., Chersonesus in the Crimea : Early Byzantine capitals with fine-toothed acanthus leaves, in G. R. Tsetskhladze (ed.), The Black Sea, Paphlagonia, Pontus and Phrygia in Antiquity. Aspects of archaeology and ancient history (BAR Intern. Series, 2432), Oxford, 2012, p. 129-140.

${ }^{16}$ L. G. KHRUSHKOVA, Book review: S. B. SOROČAN, op. cit. (n. 114), in Arkheolohiya 2, Kyiv, 2009, p. 103-108. 


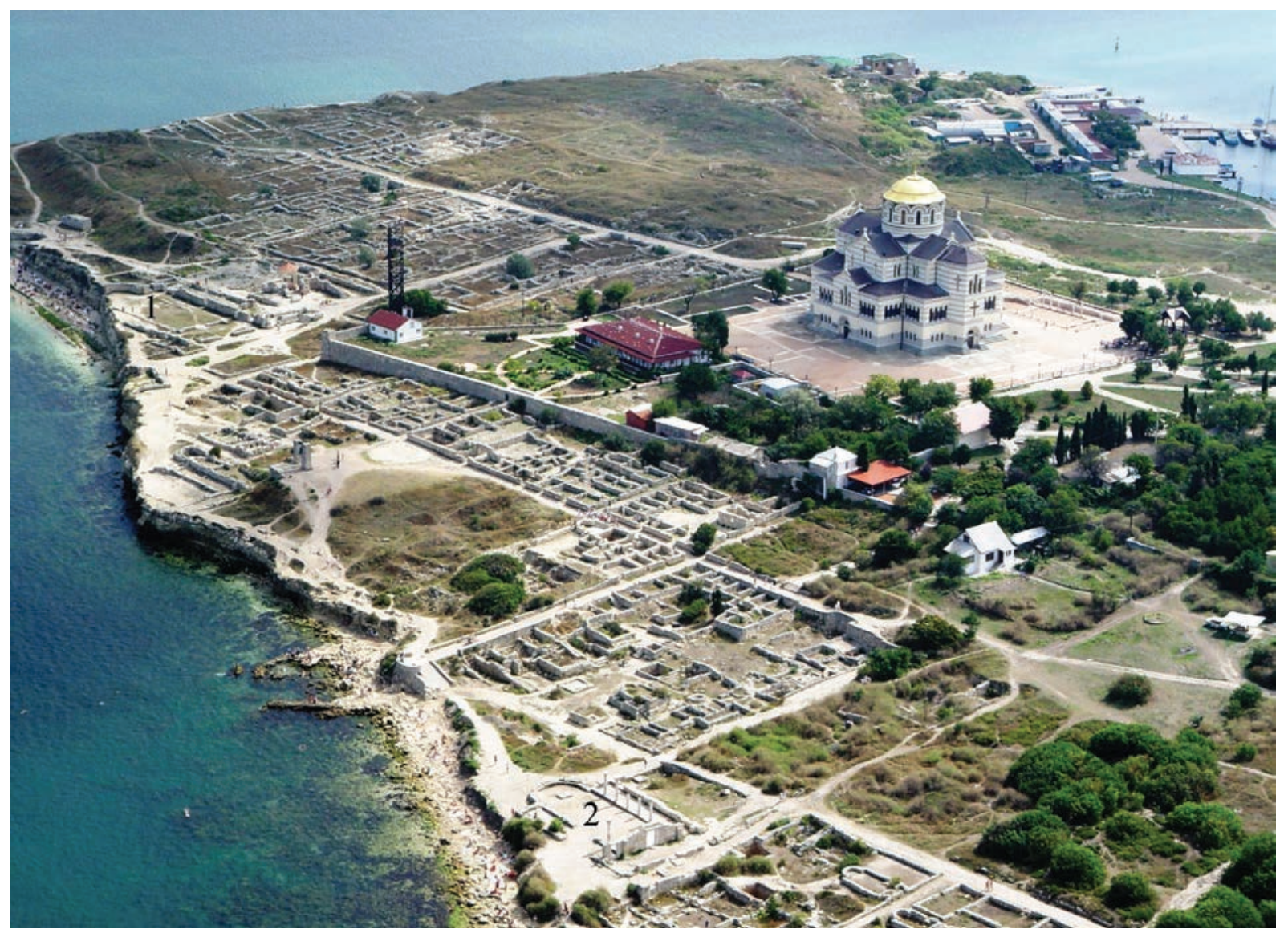

Fig. 20. Site of ancient settlement of Chersonesos, view to the East: 1- Uvarov's basilica, 2 - "Basilica 1935" (photo V. A. Filippov)

archaeological materials, in particular, the ceramics and the numismatic findings. The architectural type of the church, the masonry technique and some other features played only a secondary role in the process of dating and may be used only if there are some comparable edifices, which are dated more precisely by written or archaeological evidence". The main means to establish "an absolute chronology" was the collecting of information on the findings of pottery and coins from the publications and archives. In this way, "on the basis of archaeological materials, the chronology of most of the churches was clarified". In the author's opinion, their construction likely began in the age of Justinian and was completed in the first half of the $7^{\text {th }}$ century ${ }^{117}$.

Zavadskaya's thesis empirically answers the question of whether it might be possible to date an architectural monument without considering its architectural features, construction technique and ornamentation. The negative answer is implied in Zavadskaya's work itself: "<...> most of the churches of Chersonesos were investigated at the time when excavations were carried out to the rock without any fixation of layers. For this reason, the dating of a number of monuments remains problematic" ${ }^{118}$. Indeed, on the one hand the chronology of the churches of Chersonesos remained problematic, as before, while on the other hand, Yakobson's chronology was, in principle, confirmed. There is, in fact, only one exception, Uvarov's basilica, which will be discussed below.
Archaeological artifacts from unprofessional excavations carried out by Kostsiuško-Valyužinič are not suitable for establishing the chronology of architectural monuments; we do not know from where these items came. There are some deeper-rooted reasons too. The possibility of using archaeological artifacts for dating depends on the features of the architectural monument as a particular type of archeological site, with its own peculiarities in the accumulation of the "occupational levels". For such a site the methods which are used for studying settlements with undisturbed "occupational levels" are not applicable. There is an example in Chersonesos, which has already become a common place, namely the cruciform cemetery church of the $6^{\text {th }}$ century, where some fragments of medieval glazed ceramics accidentally got under the mosaic pavement of the early Byzantine times. Their date obviously did not correspond to the architecture of the church and its mosaics, so the dating from $10^{\text {th }}$ $-12^{\text {th }}$ centuries suggested by Oleg I. Dombrowskij on account of these findings, was not accepted ${ }^{\mathrm{n}}$.

Repeated repairs, reconstructions, construction of a new floor, various interventions in the process of the additional constructing and renovation etc.) violated the integrity of the occupation layers and make the architectural monument an "open complex". In such obstacles, a coin or other item accidentally fell under the pavement or wall, not necessarily dates this architectural element. And, beyond that, very often the bulk material - ceramics, can't be dated precisely

${ }^{117}$ I. A. ZAVADSKAYA, Khronlogiya pamyatnikov rannesrednevekovoj khristianskoj arkhitektury Khersonesa (po arkheologičeskim dannym), in Materialy po arkheologii, istorii i etnografii Tavrii 7 , Simferopol', 2000, p. 78, 83.

${ }^{118}$ IBID., p. 78.

${ }^{19}$ T. YU. YAŠAEVA, Krestoobraznyj zagorodnyj khram, in A. B. Biernacki et al. (eds.), op. cit. (n. 6), p. 93-98; L. G. KHRUSHKOVA, O načale khristianskogo Khersonesa Tavričeskogo: krestovidnaya tserkov' na glavnom kladbišče, in N. V. Kukoval'skaya (ed.), Sugdejskij sbornik 2, Kiev-Sudak, 2005, p. 393-420. 
with suitable credibility ${ }^{120}$. Alla I. Romančuk rightly noticed: "When using archaeological evidence one can't help have doubts in the chronological attribution of the various groups of archaeological findings"; "And the root of such ambiguity lay not just in the method of excavation, but in the fact that the findings that underlie the chronological patterns don't belong only to certain narrow period"121.

The method of dating of the architectural monuments drawn entirely on scattered findings may be seen as a reflection of an "artifact-centric" approach of the end of the $19^{\text {th }}$ century, when the architectural monument was not considered as the main artefact, was not in the focus of attention of the researchers. It is not unexpected that till now, together with the old methods the old datings by KostsyuškoValyužinič and Berthier-Delagarde have been repeated.

Uvarov's basilica (fig. 20) presents the striking example of the applying of this "neo-artifact-centric" method. The

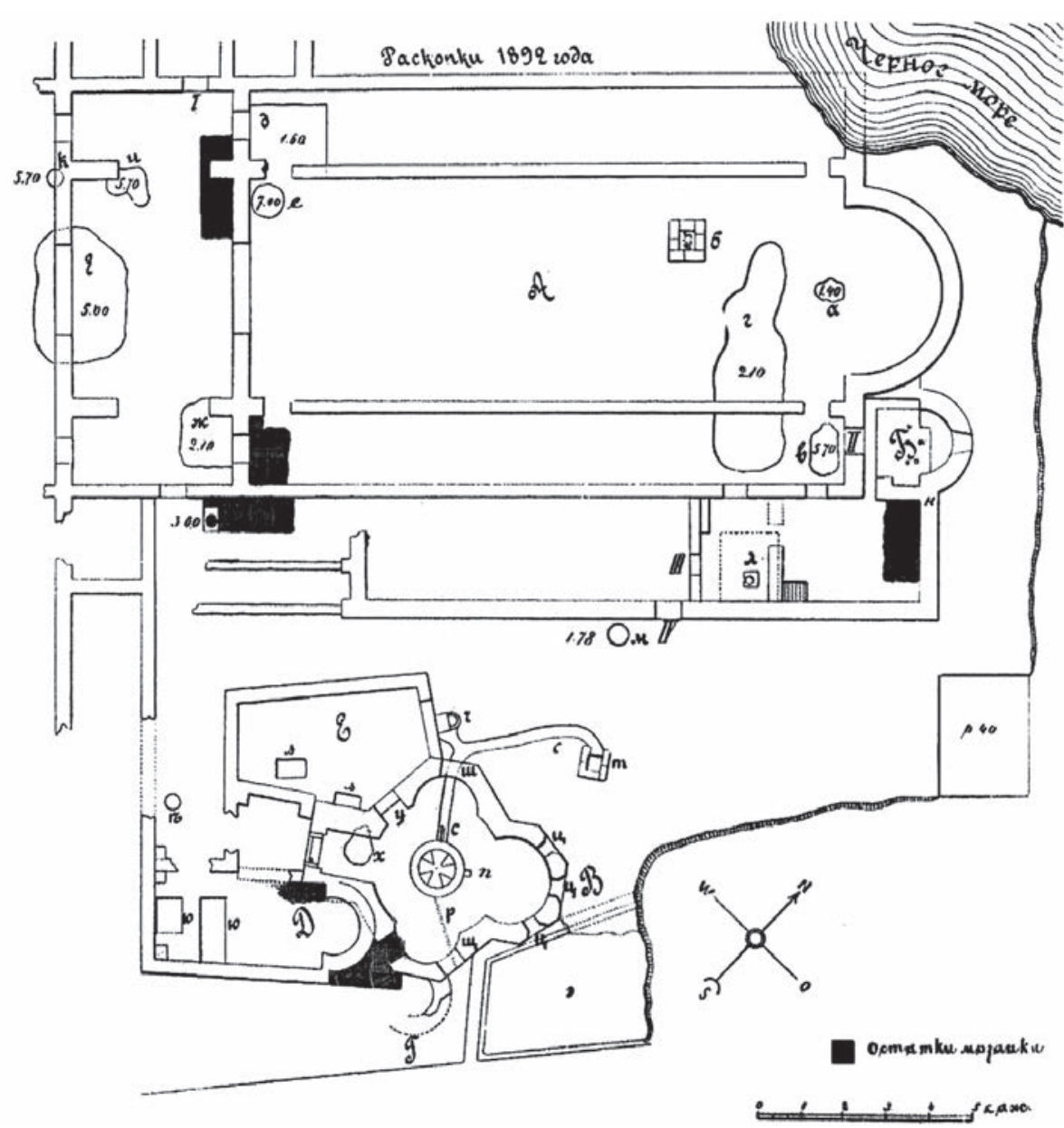

Fig. 21. Uvarov's basilica, plan, M. I. Skubetov (after: M. I. Skubetov, 1902) recent discussions on its date focus on only one item: the coin of Mauricius (582-602), which Kostsyuško-Valyužinič found in the ground-pile in the well under the western wall of the narthex ${ }^{122}$. Meanwhile "no other findings dated from the time of construction of the complex, had been recorded by reason of the shortcomings of the archaeological methods"; Zavadskaya refined a little the date of the coin, attributing it to the 70's of the $6^{\text {th }}$ century ${ }^{123}$. But it does not change the situation. This date doesn't not match the features of the architecture, so Yakobson proposed the hypothesis of two construction periods: the basilica was built in the $5^{\text {th }}$ century, but the wall of the narthex belongs to the later period ${ }^{124}$.

Kostsyuško-Valyužinič did not take into account the important fact that the well was only partially blocked by the wall, therefore, it is not a "closed complex". ElenaYu. Klenina rightly noticed that Mauricius coin could found its way in the well when it was already filled $u^{125}$. Romančuk explains the appearance of the coin in the well in the following way. "The wall of the narthex was dismantled and constructed again <...> One might really offers a different explanation: some ground was for some unknown reason dug out of the two-thirds of the well, which is not overlapping by the wall of the narthex and the coin was put there"126. In my opinion, "the phenomenon of the coin" may be easily clarified. The well was filled up with the ground more loose than the rock on which the basilica stood, so the part of the pavement over the well inevitably was deformed and ruined. Then the Mauricius coin fell into the well, producing the deceptive "stratigraphic" picture. It is enough just look at the drawing made from life after the excavations (fig. 21) which shows clearly the relative position of the walls of the narthex and the well. It seems that the participants of the discussions, which are conducted with great temperament, did not pay attention to this document. The similar situation may be observed in the case of the medieval glazed pottery under the $6^{\text {th }}$ century pavement of the suburban cruciform church, which had been mentioned above.

Fortunately enough, recent re-excavations sometimes resulted in success. The obvious example is the tetraconchal church in the south-west area of the ancient town of Chersonesos. Since the end of the $19^{\text {th }}$

\footnotetext{
${ }^{120}$ For more details see: L. G. KHRUSHKOVA, Bazilika v Partenitakh (Yužnyj Krym): mog li byt’v nej pokhoronen episkopIoann Gotskij?, in T. YU. Yašaeva (ed.), Klimentovskij Sbornik, Materialy VI Meždunarodnoj konferentsii “Tserkovnaya arkheologiya”, Sevastopol', 2013, p. 385-387.

${ }^{121}$ A. I. ROMANČUK, op. cit. (n. 6), p. 306

${ }^{122}$ K. K. KOSTSYUŠKO-VALYUŽINIČ, Otčet o raskopkakh v Khersonese v 1901 g., in Izvestiya Arkheologičeskoj komissii 4, 1902, p. 8o, 95; A. L. BERTHIERDELAGARDE, op. cit. (n. 36), p. 75, 78, 80.

${ }^{123}$ I. A. ZAVADSKAYA, op. cit. (n. 117), p. 79, note 2, p. 8o.

${ }^{124}$ A. L. YAKOBSON, op. cit. (n. 87), p. 152-16o.

${ }^{125}$ E. YU. KLENINA, op. cit. (n. 6), p. 74-75. In another paper Klenina dates the basilica from the end of the $5^{\text {th }}-$ the beginning and first half of the $6^{\text {th }}$ century; in this paper she doesn't mentionted Mauricius coin, bet referred to unpublished archive materials: E. YU. KLENINA, The Bishopric and Early Christian Architecture in Chersonesus Taurica, in O. Brandt et al. (eds.), Acta XV CIAC, Toleti (8-12.9.2008), Città del Vaticano, 2013, p. 918-919, 922. In her earlier work Klenina dated the basilica from the end of the $4^{\text {th }}-$ the beginning of the $5^{\text {th }}$ century: E. YU. KLENINA, The saint martyrs of Chersonesos according to written and archaeological sources, in Khersonesskij sbornik 15, Sevastopol', 2006, p. 118.
}

${ }^{126}$ A. I. ROMANČUK, op. cit. (n. 6), p. 280. 
century it was excavated many times by different archaeologists, among them by Kostsyuško-Valyužinič (1906). The most fruitful were the excavations in 1977-1979. Probably for the first time in the history of the studies of the Byzantine architecture of Chersonesos Oleg I. Dombrowski and Vadim A. Kutajsov excavated carefully the monument and revealed the whole complicated stratigraphic pattern (ten layers), in which the remnants of the church are included. On the base of archaeological and numismatic materials the tetraconchal church may be dated from the period the end of the $5^{\text {th }}$ - the third quarter of the $6^{\text {th }}$ century. This research has been carried out (not without argues) 35 years and the publication of the results has been completed only in $2014^{127}$.

Another example of the successful revisory excavations of the familiar monument is the "Kruze" basilica (fig. 22). The excavations carrying out over the last years by Sergei V. Ušakov resulted in the finding of a lot of archeological evidence which certainly proved that the church was constructed about the middle of the $6^{\text {th }}$ century ${ }^{128}$.

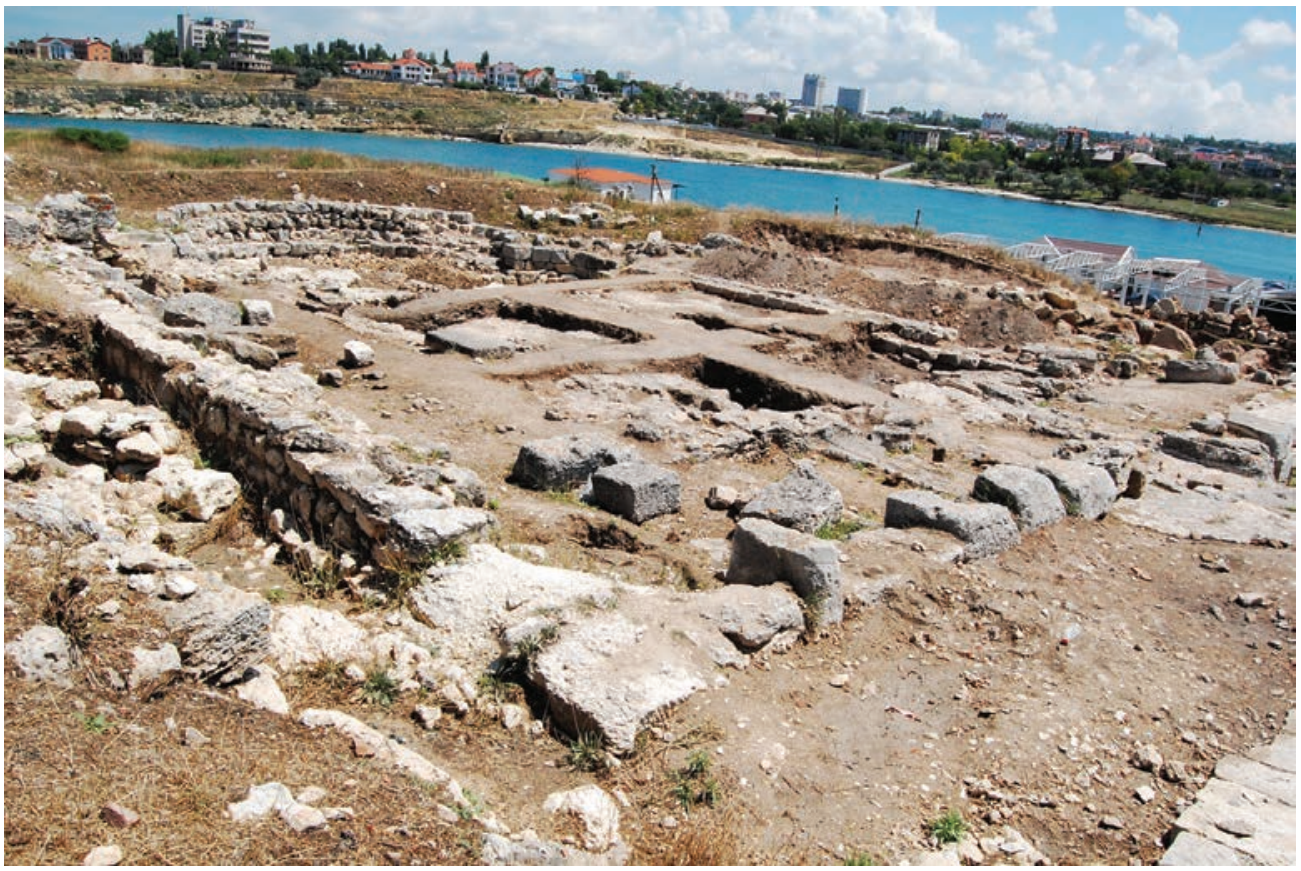

Fig. 22. "The Kruze Basilica", view to the South-East (photo L. Khrushkova)

During the last 25 years several studies on the early Christian monuments in the different regions (including the nearest to the Crimea Black Sea area) were published in Russia and in the East and Central European countries ${ }^{129}$. Chersonesos is an exception, the last "unconquerable fortress".

\section{ABBREVIATIONS}

CIAC - Congressus internationalis archaeologiae christianae

DACL - Dictionnaire d'archéologie chrétienne et de liturgie

DOP - Dumbarton Oaks Papers

RQ - Römische Quartalschrift

VV - Vizantijskij Vremennik

\footnotetext{
127 V. A. KUTAJSOV, A. A. TRUFANOV, Bassejn pod četyrekhapsidnym khramom v Khersonese (raskopki 1977-1979), in Istoriya i arkheologiya Kryma 1, Simferopol', 2014, p. 234-253.

${ }^{128}$ S. V. UŠAKOV, Bazilika "Kruze": istoriya izučeniya pamyatnika, in Khramozdatel ' 1 (2), 2013, p. 58-59.

${ }^{129}$ P. CHEVALIER, Salona II - Ecclesiae Dalmatiae 1-2, Rome; Split, 1995; N. ČANEVA-DEČEVSKA, Ranno-khristiyanskata arkhitektura v Bylgariya IV-VI v., Sofiya, 1999; D. GÁSPÁR, Christianity in Roman Pannonia. An evaluation of Early Christian finds and sites from Hungary (BAR Intern. Series, 1010), Oxford, 2002; L. G. KHRUSHKOVA, Rannekhristianskie pamyatniki Vostočnogo Pričernomorya. IV-VII veka, Moscow, 2002; EAD., Les monuments chrétiens de la côte orientale de la mer Noire. Abkhazie. IVe-XIVe siècles (Bibliothèque de l'Antiquité Tardive, 9), Turnhout, 2006; A. KAZARYAN, Tserkovnaya arkhitektura stran Zakavkazya VII veka. Formirovanie i razvitie traditsii 1-4, Moscow, 2011-2012.
} 